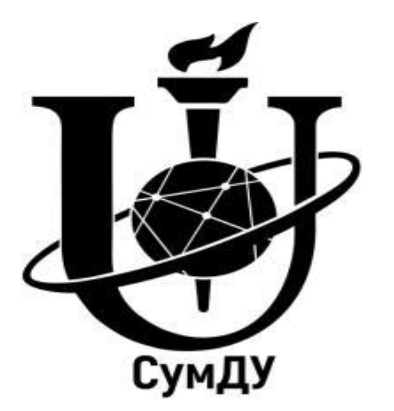

Ministry of Education and Science of Ukraine Sumy State University

Academic and Research Institute of Business

Technologies "UAB"

I. Ye. Yarova

\title{
INTERNATIONAL LOGISTICS
}

Lecture notes

\author{
Sumy \\ Sumy State University \\ 2020
}


Ministry of Education and Science of Ukraine Sumy State University

Academic and Research Institute of Business Technologies

"UAB"

\section{INTERNATIONAL LOGISTICS}

for students of specialty 292 "International Economic Relations" full-time course of study

Approved at the meeting of the Department of International Economic Relations as lecture notes on course "International Logistics". Minutes № 12 of 28.04.2020.

Sumy

Sumy State University

2020 
International Logistics : lecture notes / compiler I. Ye.Yarova. - Sumy : Sumy State University, 2020. - 150 p.

Department of International Economic Relations of Academic and Research Institute of Business Technologies "UAB" 


\section{Contents}

Introduction......................................... 5

Chapter 1: Fundamentals of International Logistics ........ 7

1.1. Logistics as an Instrument of the Market Economy..... 7

1.2. Basics of International Logistics................... 9

1.3. Logistics in the Enterprise Management

System

Chapter 2: Conceptual Foundations of International Logistics.

26

2.1. Supply Chain Management (SCM) as a New Business

Concept

2.2. Logistics System and Logistics Cycle

2.3. Organization of Logistic Flows ................... 34

Chapter 3: International Aspects of Procurement Logistics. 38

3.1. Theoretical Foundations of Procurement Logistics..... 38

3.2. Basic Approaches to Choosing a Supplier............. 39

3.3. Economic Order Quantity ........................ 42

3.4. The "Just-in-Time" (JIT) Logistics.................. 43

Chapter 4: Logistics of International Stocks.............. 49

4.1. Theoretical Fundamentals of Inventory Logistics...... 49

4.2. Inventory Management.............................. 53

4.3. Analysis of ABC-XYZ in the Inventory

Management ....................................... 56

4.4. Vendor Managed Inventory (VMI) ................ 60

Chapter 5: International Warehouse Logistics ................ 65

5.1. Warehouses: Definition, Functions

And Classification.................................... 65

5.2. Warehouse Logistics.......................... 70 
5.3. Packaging and Barcoding........................ 73

Chapter 6: Production Logistics ....................... 78

6.1. Theoretical Fundamentals of Production Logistics... 78

6.2. Logistics Concepts: "MRP" vs "ERP” Systems..... 80

6.3. Lean Manufacturing ............................ 88

6.4. Kanban as a Micrologistics System................ 90

6.5. Optimized Production Technology ................. 99

Chapter 7: Distribution Logistics...................... 105

7.1. Fundamentals of Distribution Logistics............. 109

7.2. Distribution Logistics Channel..................... 115

7.3. Logistics Intermediaries in Distribution Channels... 119

7.4. Distribution Centers in Logistic Chains.............. 122

7.5. Distribution Requirement Planning (DRP).......... 124

Chapter 8: Fundamentals of International Transport Logistics...................................... 131

8.1. Definition and Objectives of Transport Logistics... 131

8.2. Forwarding Service ............................ 136

References........................................ 144 


\section{Introduction}

The purpose of the course "International Logistics" is to develop knowledge and practical skills of conceptual bases and aspects of international logistics activities, as well as methods, means of forming logistics systems, transport support of international business and trends in its development.

The main tasks of the course are:

- formation of knowledge about methods of logistics management;

- implementation of the system vision on the logistical component of the globalization processes;

- identification of the peculiarities of transport in the process of international relations development;

- acquiring practical skills of customs brokers;

- definition of strategic directions of international logistic systems development.

After successful completion of the course the students will be able:

- to identify and analyze the theoretical and conceptual bases, aspects of international logistics, as well as its peculiarities at the global and regional levels, in the activities of integration groups of countries and transnational corporations; 
- to develop the understanding and process of knowledge of basic categories, modern logistics concepts, technologies and methods in the field of international logistics relations, taking into account their basic forms;

- to carry out a comprehensive analysis of international logistics activities globally and regionally, taking into account the monitoring of global market conditions and changes in the international environment and the ability to adapt to them;

- to determine the functional characteristics, nature, level and degree of interconnections between the subjects of international economic relations of various levels and to establish communications between them in a highly dynamic business activity - international logistics;

- to research and diagnose changes in economic phenomena and processes in the international logistics field, taking into account causal and spatial and temporal relationships, as well as to determine the place and tasks of Ukraine in the world and European transport and logistics integration. 


\section{CHAPTER 1: FUNDAMENTALS OF INTERNATIONAL LOGISTICS}

1.1. Logistics as an Instrument of the Market Economy

1.2. Basics of International Logistics

1.3. Logistics in the Enterprise Management System

Key words: logistics, international logistics, inbound and outbound logistics, business logistics, logistics concept, logistics management system.

\subsection{Logistics as an Instrument of the Market Economy}

The term "logistics" (in French "logistique") was popularized by military officer and writer Antoine-Henri Jomini, who defined it in his "Summary of the Art of War" (Précis de l'Art de la Guerre).

The Oxford English Dictionary defines logistics as "the branch of military science relating to procuring, maintaining and transporting material, personnel and facilities". However, the New Oxford American Dictionary defines logistics as "the detailed coordination of a complex operation involving many people, facilities, or supplies", and the Oxford Dictionary defines it as "the detailed organization and implementation of a complex operation" [1]. 
Logistics is the process of planning, execution and control of the movement and placement of people and/or goods and of supporting activities related to such movement and placement, within a system organised to achieve specific objectives [2].

Unification and standardization of logistics terminology abroad currently mainly engaged in two organizations: Council of Logistics Management (CLM) and European Logistics Association (ELA).

\section{Periodization of logistics development}

Fragmentation period (1920-1950) is related to the idea of cost-cutting logistics. During this period, only the preconditions for the future implementation of the logistic concept have been formulated such as:

- increase of stocks and freight costs in the distribution system of goods;

- increase in freight rates;

- emergence of marketing;

- development of military logistics theory and practice.

Formation (conceptualization) of logistics (1950 - 1970s) is characterized by the rapid growth of the theory and practice of logistics. The marketing philosophy has quickly spread, and at the same time, it has been understood that there was a necessity to develop and to improve distribution, primarily from the point 
of view of cost reduction. One of the key factors in the rapid expansion of logistics was the emergence of a total costs concept in physical distribution.

Integral logistics (1980 - 1990) is characterized by the rapid development of modern marketing and integrated logistics. The logistics function is formed: "Procurement - production - sales".

This period can be called personalization. With the development of new trade relations and the elimination of state monopoly, the principle of business logistics became widely used.

Factors that have influenced the formation of commercial logistics:

$-1950 s-$ the overproduction crisis in the United States;

- 1970s - the global energy crisis;

-1980s-development of information technology;

$-1990 s-$ decoupling of transport enterprises.

\subsection{Basics of International Logistics}

The concept of logistics is based on a total system view of the multitude of functions in movement of materials and goods from sources of supply to users. Accordingly, it forces management to think in terms of managing the total system, rather than just one part of it. 
According to the Council of Supply Chain Management Professionals (previously the Council of Logistics Management), logistics is the process of planning, implementing and controlling procedures for the efficient and effective transportation and storage of goods including services and related information from the point of origin to the point of consumption for the purpose of conforming to customer requirements and includes inbound, outbound, internal and external movements [3].

The most famous definition cited by most overseas university textbooks, is the definition of logistics given in the USA in 1985: "Logistics is the planning, executing and controlling process in terms of reducing the cost of raw materials stocks flow, unfinished production, finished products, service and related information from the point of its origin to the point of consumption (including import, export, internal and external movements) to fully meet customers' requirements" [4].

According to Phillip Kotler: "Market logistics involve planning, implementing and controlling physical flow of material and final (finished) goods from the point of origin to the point of use to meet customer requirements, at a profit."

The term "business logistics" has evolved since the 1960s [5] due to the increasing complexity to supply businesses with 
materials and to ship out products in an increasingly globalized supply chain, leading to a call for professionals called "supply chain logisticians". From a business point of view: "Logistics is a tool for integrated management of material and related information, financial flows, as well as ancillary services that contribute to achieving the goals of a business organization with the optimal cost of resources" [4].

In business, logistics may have either an internal focus (inbound logistics) or an external focus (outbound logistics), covering the flow and storage of materials from point of origin to point of consumption. The main functions of a qualified logistician include inventory management, purchasing, transportation, warehousing, consultation, and the organizing and planning of these activities. Logisticians combine a professional knowledge of each function to coordinate resources in an organization $[6,7]$.

The object of logistics is the flow processes, their structure and elements to achieve general and local goals and the implementation of their functions.

The main task of logistics is to achieve the maximum adaptability of economic entities (enterprises, associations) to market conditions with optimal expenses; to increase the market share and to obtain competitive advantages [8]. In this regard, 
the subject of logistics is the logistic processes associated with changes in the parameters of placement, time, the form of material and their accompanying flows at the enterprises, and the object-logistic flows (material, informational, financial, information, service and other flows).

The main objective of logistics is to adapt the firm to the market situation with the minimum costs, to increase its own presence in the market and to gain competitive advantages by creating an integrated effective system of regulation and control of material and information flows [9].

\section{Objectives of International Logistics [10]:}

1. Cost Reduction and Profit Maximization: Logistics management results in cost reduction and profit maximization, primarily due to:

- improved material handling;

- safe, speedy and economical transportation;

- optimum number and convenient location of warehouses, etc.

2. Efficient Flow of Manufacturing Operations: Inbound logistics helps in the efficient flow of manufacturing operations due to on-time delivery of materials, proper utilisation of materials and semi-finished goods in the production process and so on. 
3. Competitive Edge: Logistics provides, maintains and sharpens the competitive edge of an enterprise by:

- increasing sales through providing better customer service;

- arranging for rapid and reliable delivery;

- avoiding errors in order processing and so on.

4. Effective Communication System: An efficient information system is a must for sound logistics management. As such, logistics management helps in developing effective communication system for continuous interface with suppliers and rapid response to customer enquiries.

5. Sound Inventory Management: Sound inventory management is a by-product of logistics management. A major headache of production management, financial management etc. is how to ensure sound inventory management such a headache is cured by logistics management.

\section{Key logistics functions include:}

1. Maintaining the quality standards of subsidiary and associated services production.

2. Transportation.

3 . Inventory management.

4. Order management.

5. Support of production procedures.

Logistics may be broadly classified into two categories [10]: 
1. Inbound logistics, which is concerned with the smooth and cost effective inflow of materials and other inputs (that are needed in the manufacturing process) from suppliers to the plant. For proper management of inbound logistics, the management has to maintain a continuous interface with suppliers (vendors).

2. Outbound logistics (also called physical distribution management or supply chain management). It is concerned with the flow of finished goods and other related information from the firm to the customer. For proper management of outbound logistics, the management has to maintain a continuous interface with transport operators and channels of distribution.

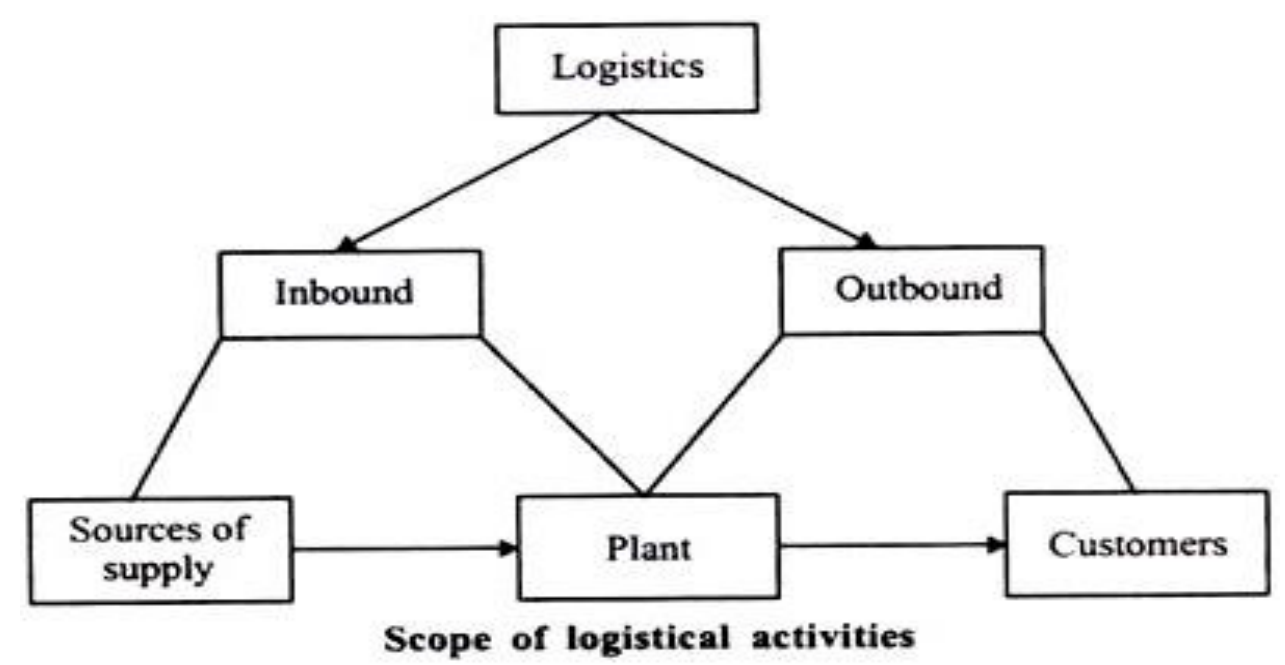

Fig. 1.1. Scope of logistical activities [10]

Depending on the services performed by logisticians, the main fields of logistics can be broken down as follows: 
1. Procurement logistics

2. Distribution logistics.

3. After-sales logistics.

4. Disposal logistics.

5. Reverse logistics.

6. Green logistics.

7. Global logistics.

8. Domestics logistics.

9. Production Logistics.

10. Construction Logistics.

11. Capital Project Logistics.

12. Digital Logistics.

According to the Council of Logistics Management, logistics is the management process of planning, implementing and controlling the physical and information flows concerned with materials and finished goods from the point of origin to the point of use. International logistics involves the management of object-logistic flows in a company's supply chain across at least the one international border [11].

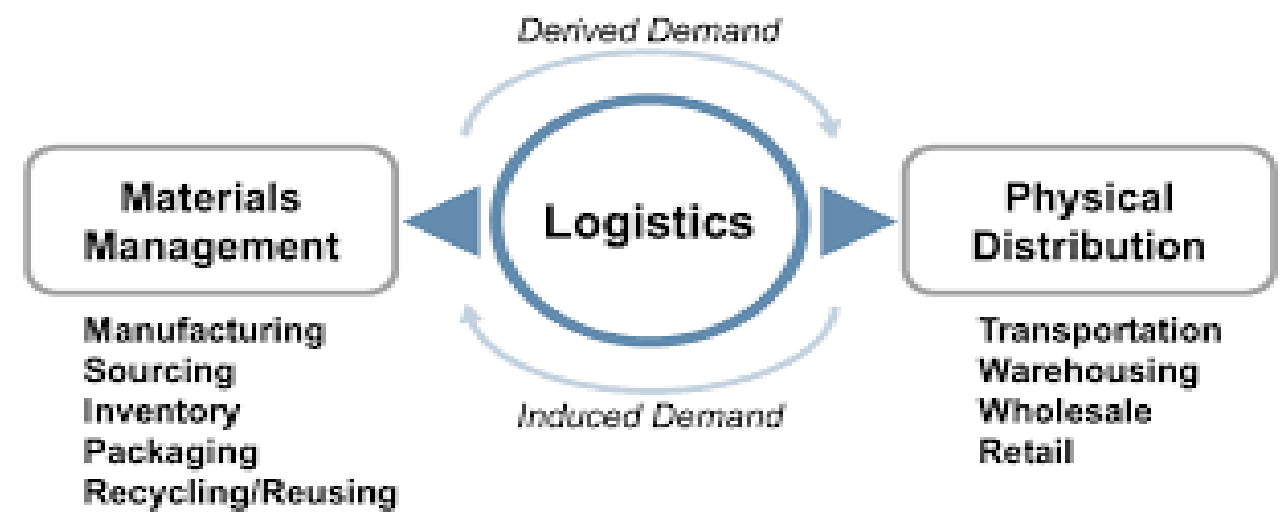

Fig. 1.2. "Driven by demand" logistics activities [11] 


\section{Key activities involved in the international logistics:}

1. Network Design: Network design is one of the prime responsibilities of logistics management. This network is required to determine the number and location of manufacturing plants, warehouses, handling equipment etc. on which logistics efficiency depends.

2. Order Processing: customers' orders are very important in logistics management. Order processing includes activities for receiving, handling, filing and recording orders. Herein, management has to ensure that order processing is accurate, reliable and fast. Further, management has to minimize the time between receipt of orders and date of shipment to ensure rapid order. Delays in the execution of orders can become serious grounds for customer dissatisfaction, which must be avoided at all costs.

3. Procurement: It is related to obtaining materials from external suppliers. It includes supply sourcing, negotiation, order placement, inbound transportation, receiving and inspection, storage and handling, etc. Its main objective is to support manufacturing by providing timely supplies of qualitative materials at the lowest possible cost.

4. Material Handling: It involves the activities of handling raw-materials, parts, semi-finished and finished goods to and 
from the plant, warehouses and transportation terminals. Management has to ensure that raw-materials, parts, semifinished and finished goods are handled properly to minimize losses due to breakage, spoilage, etc. Further more, the management has to minimize the handling costs and the time involved in material handling. Material handling systems, in logistics management are divided into three categories: mechanized systems, semi-automated systems and automated systems.

5. Inventory Management: the basic objective of inventory management is to minimize the amount of working capital blocked in inventories, and at the same time, to provide a continuous flow of materials to match production requirements; and to provide timely supplies of goods to meet customer demands.

6. Packaging and Labeling: Packaging and labeling are an important aspect of logistics management. Packaging implies enclosing or encasing a product into suitable packets or containers, for easy and convenient handling of the product by both, the seller and specially the buyer. Labeling is a powerful sales promotion tool. The consumer who is persuaded to read the label may, in fact, try to buy the product even though he/she had no such premeditation (advance idea). 
7. Warehousing: storage or warehousing is the logistics activity that creates time utility by storing goods from the time of production until the time the goods are needed by ultimate consumers. Here, the management has to decide about the number and type of warehouses needed and the location of warehouses. It depends on the desired level of customer service and the distance between the supply source and final destination - markets.

8. Transportation: Transportation is that logistics activity, which creates place utility.

The main participants (elements) of the supply chain of International Logistics may be as follows: producers, supplier (venndor), exporter of goods and services, customs broker, importer of goods and services, end user, freight forwarding companies, warehouse complexes, distributors, wholesalers, retailers, companies or individuals who are the final consumers of the product.

\section{There are several peculiarities of international logistics} such as [11]:

1. Specificity.

2. Export-import operations.

3. Customs procedures. 
4. Regulation of delivery orders, delivery point, delivery schedule and terms, under contracts of purchase on the basis of Incoterms and international rules of carriage conditions.

5. Registration of transport, goods and accompanying documents.

6. Insurance.

The peculiarities and complexity of international logistics are defined by the formula «four D»: differentiation of means of transport, documentation, differentiation of cultures, dictatorship of consumer demand.

\subsection{Logistics in the Enterprise Management System}

Logistics is the management which synchronizes such providing activities as procurement, production, sales, and distribution with demands. It aims to enhance corporate competitiveness and increase corporate value by realizing fulfillment of customer satisfaction, cutback of unprofitable inventory and minimization of its transfer, and reduction of supply costs $[11,12]$.

Logistics management consists of the process of planning, implementing and controlling the efficient flow of raw materials, work-in-progress and finished goods and related 
information from point of origin to point of consumption; with a view to provide satisfaction to the customer [11].

The concept of logistics is defined as a system of views to improve the production and economic activity of the enterprise through the streamlining of management of flow processes.

The modern concept of logistics is considered through study of its properties, based on categories of thinking, oriented on value and utility; system approach; total (full) expenses; service and efficiency (Fig.1.3).

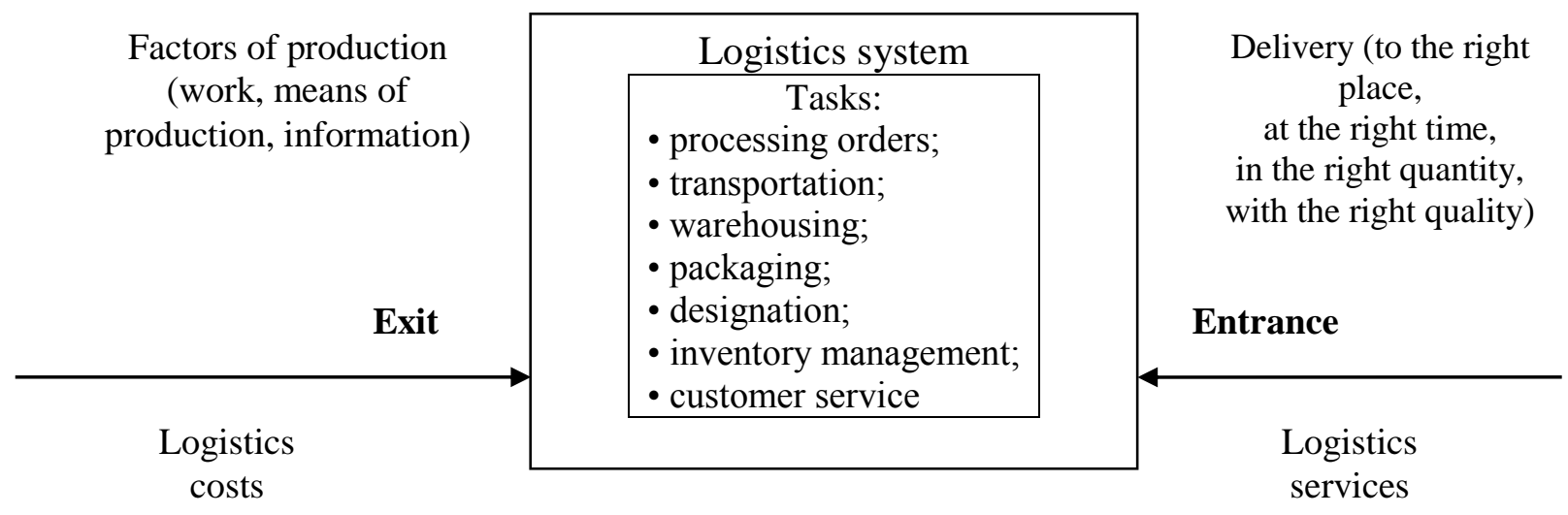

\section{Fig. 1.3. Properties of the logistics system [8]}

Such providing actions as procurement, production, sales, and distribution were managed based on sector-specific evaluation indicators in the past. These optimum activities for individual sectors resulted in significant managerial losses including stock shortage, and excessive or bad inventory. Under the circumstances where synchronization of providing actions with trends for demands was required in order to eliminate such losses, logistics as management optimizing the entire providing 
actions developed. In logistics, all the providing actions function to synchronize with trends for demands $[13,14]$.

For management, logistics is required to contribute to gain in profits by cutting down supply costs and to reduce assets by lowering inventory.

During the process of formation and development of logistics, there was a consistent change in the perceptions about the essence of its concept and methodology, as a response to the change of priorities and the consumer market needs (Fig. 1.4).

60s years of the twentieth century.

Fragmental connections
80 s of the twentieth century.

Integrated connections

Information control of the

formation and movement

of material and financial flows

Inventory of products

Warehousing

Cargo processing

Packaging

Distribution

Distribution planning

The rule of orders

Transport

Customer service

Prediction of demand

Purchase

Analysis of consumer
90 s years of the twentieth century.

Global Integration

Fig. 1.4. The main stages of logistics formation as a concept of enterprise management $[8,13]$ 
Logistics in the enterprise management system:

1) supports the market orientation of the company, aims at offering the best service to the customers (level and quality of service);

2) contributes to increasing the transparency of the market, as well as the elasticity and ability of enterprises to adapt to changing market conditions;

2) focuses on the promotion of sales and services;

3) aims to use synergies and effects;

4) provides the opportunity to solve problems arising at the junctions of movement of goods and information with other spheres in the enterprise (marketing, production, finance, personnel, etc.);

5) generates and stimulates the management efficiency.

The relationship between logistics and management can be presented as follows [11, 13, 14]:

\section{Creation and evaluation of logistics business} management indicators. For management, logistics contributes to an increase in cash flow and return on assets (ROA) by reducing inventory assets through appropriate inventory and supply costs and by improving the total asset turnover. It is necessary to reorganize businesses from a logistics point of view in the relationship with each sector such as procurement, 
production, sales, and distribution as well as business partners, and to create, manage, and operate evaluation indicators such as KPI (key performance indicator).

\section{Training for a chief logistics officer (CLO) and} restructure of organization functions. In order to plan and establish optimization of a supply chain as a managerial strategy, training and assignment of a CLO who integrates and manages performances using business management indicators and key performance indicator (KPI) are important issues. At the same time, it is essential to reorganize functions to make logistics work well in management organization.

3. Establishment of appropriate service levels such as transaction conditions. In order to build a win-win relationship between each company comprising supply chains, it is important to establish appropriate service levels by reviewing transaction conditions and others, and to minimize costs and environmental load.

\section{Conclusions}

1. During the period of logistics development, the nature of physical distribution, as the main part of marketing, has been explored, pointed to its special role in organizing and improving the efficiency of goods sales. The formation of the marketing 
concept has become a key factor to explain the emergence of logistics in business.

2. Logistics is the process of planning, execution and control of the movement and placement of people and/or goods and supporting activities related to such movement and placement, within a system organised to achieve specific objectives.

3. The main objective of logistics is to adapt the firm to the market situation with the minimum costs, to increase its own presence in the market and to gain competitive advantages by creating an integrated effective system of regulation and control of material and information flows.

4. The main difference between international logistics and national (domestic) logistics is the fact that the delivery process involves crossing state borders and customs.

5. Logistics management consists of the process of planning, implementing and controlling the efficient flow of rawmaterials, work-in-progress and finished goods and related information from the point of origin to the point of consumption; with a view to provide satisfaction to the customer. 


\section{End-of-chapter Questions:}

1. Where did the term "logistics" originate from and what are its dictionary definitions?

2. Is there a generally accepted (standard) definition of logistics?

3. What is a contemporary interpretation of logistics from the position of business?

4. What is the object of research in logistics?

5. What is the subject of research in logistics?

6. What are the logistic functions and how are they classified?

7. Why are the logistic functions divided into the key and supporting ones?

8. What parameters characterize the key logistic functions?

9. What is the role of logistics in the enterprise management system?

10. What is the main distinction between the national and international logistics? 


\section{CHAPTER 2: CONCEPTUAL FOUNDATIONS OF INTERNATIONAL LOGISTICS}

2.1. Supply Chain Management (SCM) as a New Business Concept

2.2. Logistics System and Logistics Cycle 2.3. Organization of Logistic Flows.

Key words: Supply Chain Management (SCM), logistics chain, logistics channel, logistics networks, logistics system, logistics cycle, logistic flows, material logistic flows, financial logistic flows, information and service logistic flows.

\subsection{Supply Chain Management (SCM) as a New Business Concept}

Supply Chain Management (SCM) is the integration of key business processes that begin with the end user and cover all suppliers of goods, services and information that add value to consumers and other stakeholders [15].

Supply Chain Management (SCM) is the integration of eight key business processes such as [16,13]:

1. Management of relations with consumers.

2. Customer service.

3. Demand management.

4. Order management.

5. Support of production processes. 
6. Supply management.

7. Management of product development and its derivation for commercial use.

8. Management of material flows.

The supply chain is defined as the unification of all types of business processes (design, production, sales, service, procurement, distribution, resource management, supporting functions) necessary to meet the demand for products or services

- from the initial point of raw material or information receipt to the delivery point (Fig. 2.1).

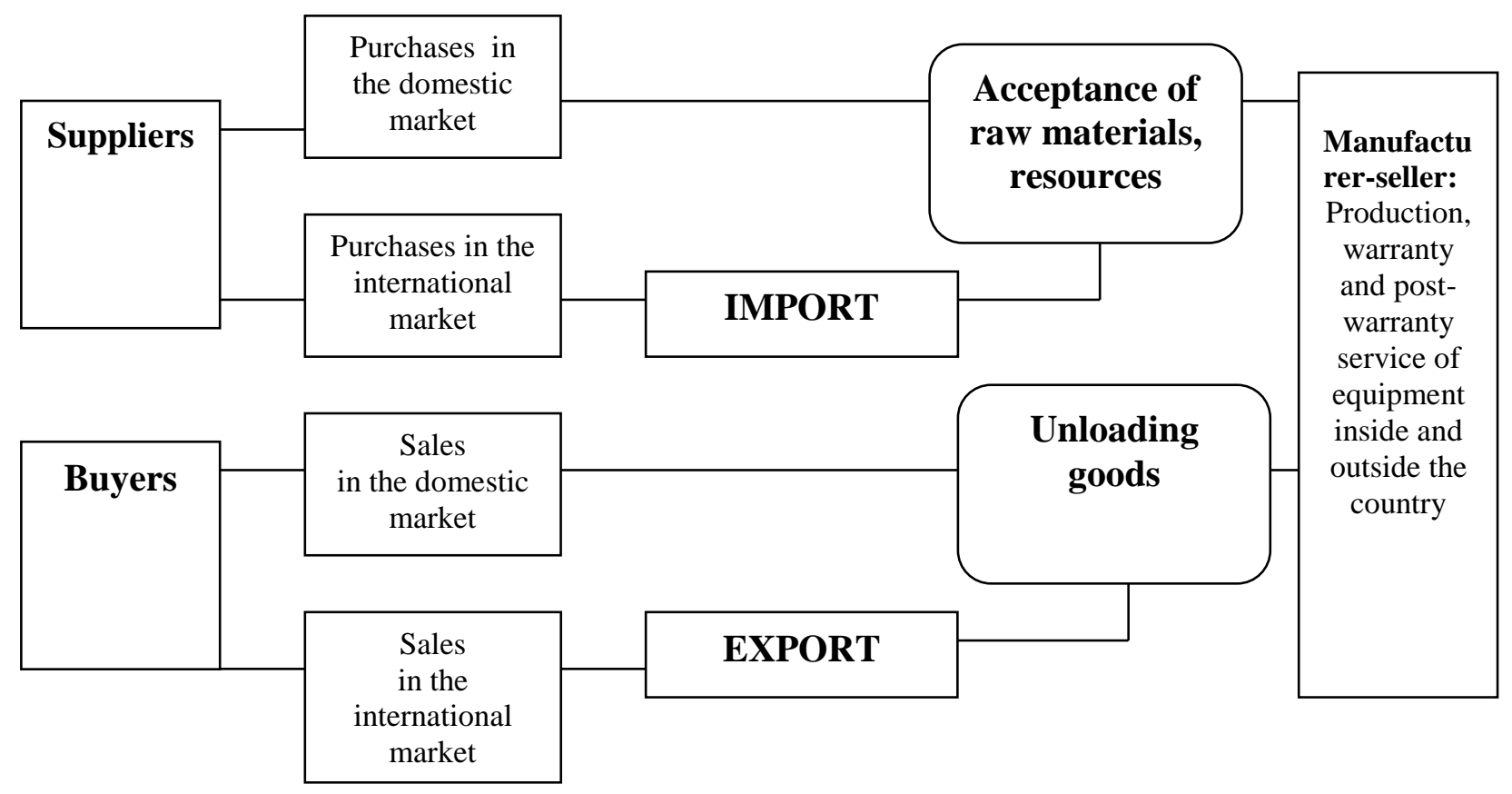

\section{Fig. 2.1. Supply Chain Management as a new business}

\section{concept $[16,17,18]$}




\section{Typical tasks for the SCM:}

1. Formation of the network structure of raw materials and finished products to reduce operating logistics costs;

2. Optimization of the scheme of transport operations / routes (in terms of costs);

3. The choice made by the manufacturer of the goods for delivery to a specific regional market [18].

Logistics chain is a linearly ordered number of individuals or legal entities (producers, intermediaries, warehouses, etc.) that perform logistics operations aimed at bringing the external material flow from one logistics system to another or to the end user. In any given supply chain there is a combination of companies who perform different functions. There are companies - producers, companies that are distributors or wholesalers, companies - retailers, and companies or individuals that are the customers - the final consumers of the product $[18$, 19]. 


\section{Extended Supply Chain}

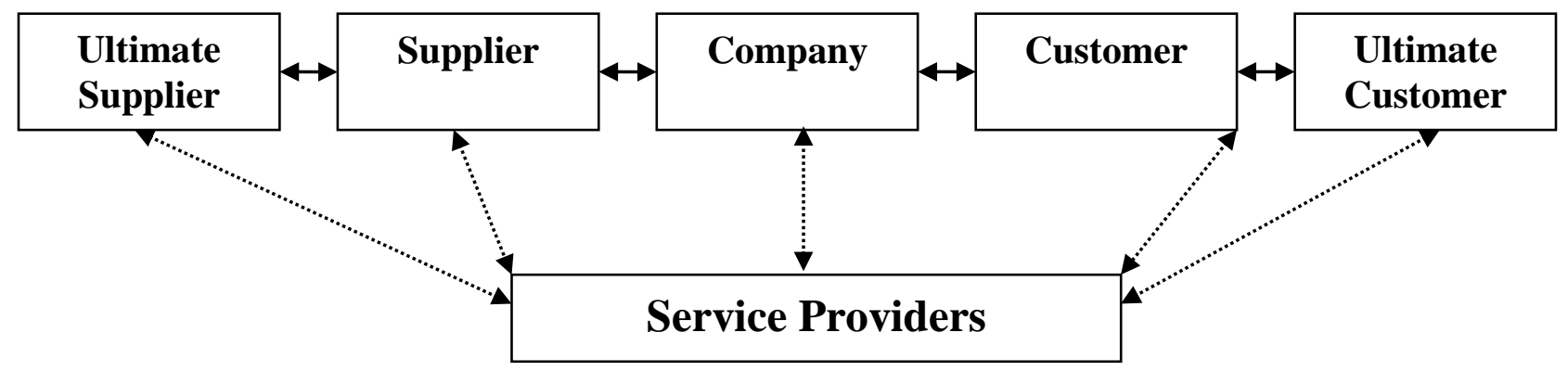

Fig. 2.2. Extended Supply Chain [18]

Producers or manufacurers are organizations that make a product. This includes companies that are producers of raw materials and copmanies that are producers of finished goods (raw materials and work-in-process made by other producers to create their own products).

Distributors are companies that take inventory in bulk from producers and deliver a bundle of related product lines to customers. Distributors are also known as wholesalers. They typically sell to other businesses and they sell products in larger quantities that an individual consumer would usually buy. Distributors buffer the producers from fluctuations in product demand by stocking inventory and doing much of the sales work to find and service customers. A distributor is typically an organization that takes ownership of significant inventories of products that they buy from producers and sell to consumers. 
Retailers stock inventory and sell insmaller quantities to the general public. This organization also closely tracks the preferences and demands of the customers that it sells to. It advertises to its customers and often uses some combination of price, product selection, service, and convenience as the primary draw to attract customers for the products it sells.

Customers or consumers are any organization that purchase and use a product. A customer organization may be an organization that purchases a product in order to incorporate it into another product that they in turn sell toother customers. Or a customer may be an end user of a product, who buys the product in order to consume it.

The logistics channel is a partially ordered set of various intermediaries that implement the proof of the material flow from a particular manufacturer to its customers.

Logistic networks are logistic entities of interconnected units, which combine several logistic chains.

The length of the channel determines the number of levels. The level of the distribution channel is any intermediary performing one or another work on the approach of the product and ownership of it to the final customer (end user).

The width of channel - the number of intermediaries at each level of the distribution channel. It is worth knowing that 
between the participants of the same channel, as well as between different channels, can be observed different degrees of cooperation; conflicts; competition [20].

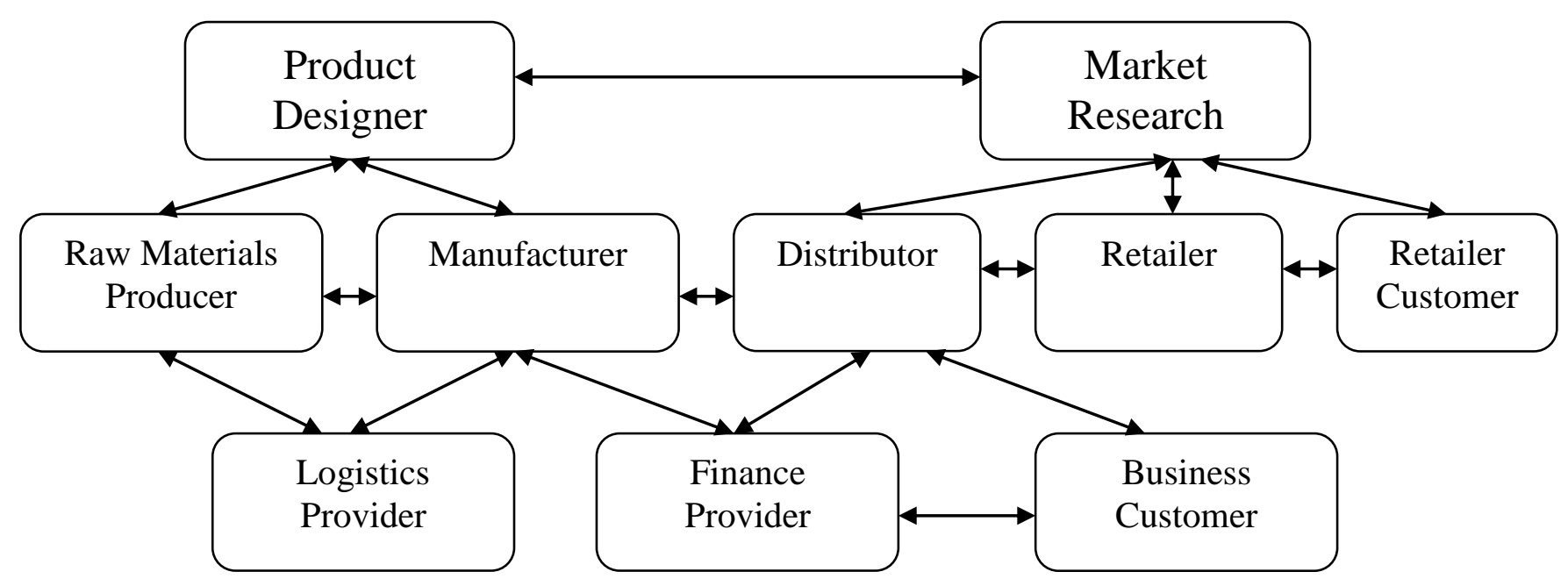

Fig. 2.3. Example of Extended Supply Chain [18]

The key to improve supply chain management is in making accurate forecasts to customer demand and managing the interactions between producers, distributors and retailers so as to meet customer demand. And to do so at the lowest operating costs and lowest amounts of on-hand inventory at facilities across the supply chain $[21,22]$.

\subsection{Logistics System and Logistics Cycle}

The logistics system involves process of planning and coordinating all aspects of the physical movement of materials, components and finished products to minimize costs and 
provide the desired level of service. The logistics system is a network of organizations, people, activities, information, and resources involved in the physical flow of products from supplier to customer (Fig. 2.3).

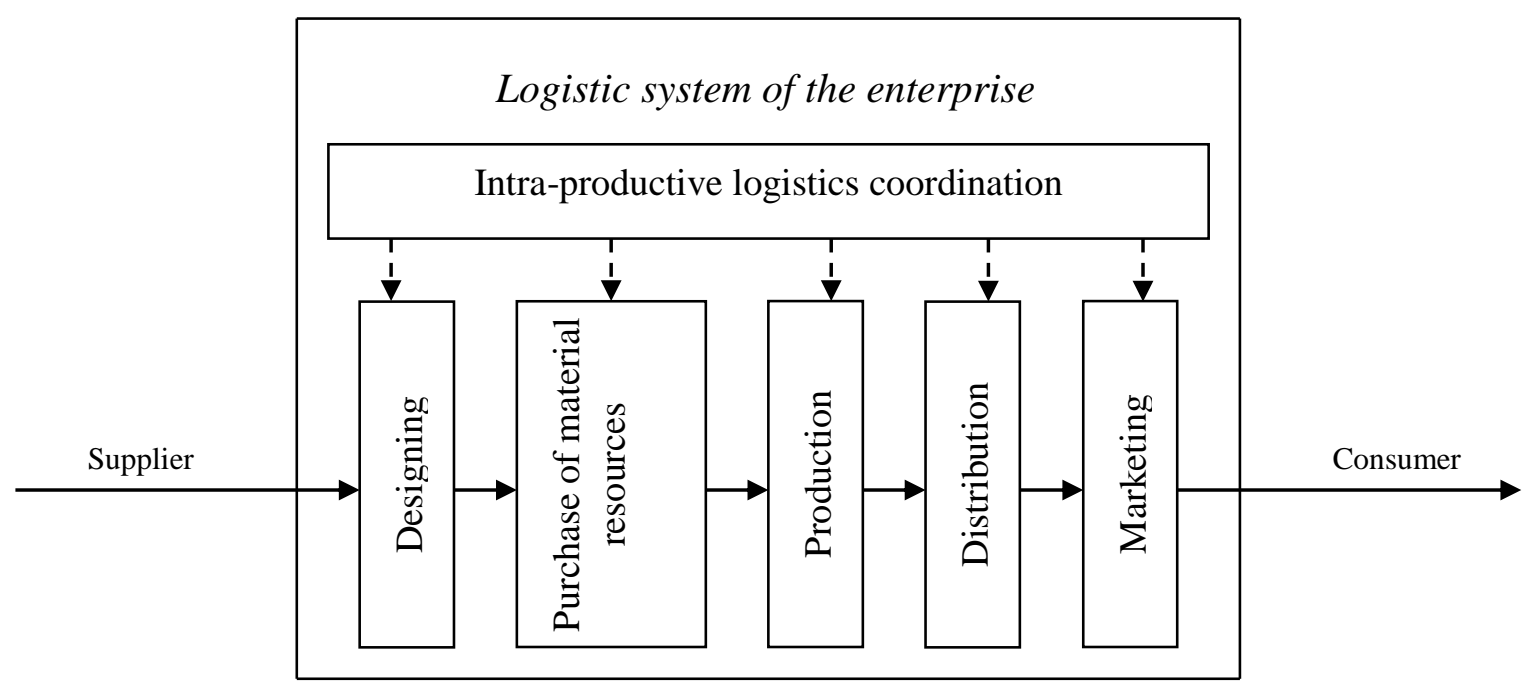

Fig. 2.3. A logistics approach to the formation of enterprise production activity [8]

The purpose of the logistics system is to ensure the delivery of goods, services to a given place in the required quantity and assortment, maximally prepared for production or personal consumption at the certain level of costs.

Subjects of the logistics system are industrial and trading enterprises, a set of industrial and infrastructure elements, as well as the links between them at different levels.

Elements of the logistics system are functionally separate objects that are not subject to further division within the framework of the task of analysis and synthesis of the logistic 
system that fulfill their local target function related to the execution of certain logistic procedures.

The objects of logistics system management are the processes, operations and corresponding procedures, which are subject to the forecasting, analysis and management in time and space, which are realized in the logistic system in order to minimize costs, productive inter-system interaction, etc.

Macrologistics system is a large economic system of flow management, which includes enterprises and organizations of industry, supply and marketing, transport and other intermediary structures of different departments and forms of ownership, not limited to the territorial location.

Micrologistics system is an economic system that covers the internal logistics area of one enterprise or a group of enterprises united on corporate foundations.

Logistics cycle is a repeating, completed and related process that transforms the purpose (meeting the needs of the end user's needs) into a certain intended result of the demand (product and object). The logistics cycle essentially defines the structural basis of the logistics system. It is determined by such main functional resources of logistics as supply, production support and distribution $[23,24]$. 


\section{Table 2.1. The main elements of the logistics cycle $[8,4]$}

\begin{tabular}{|c|l|}
\hline Element & \multicolumn{1}{|c|}{ Content of the element } \\
\hline \multirow{3}{*}{ Supply cycle } & $\begin{array}{l}\text { 1.Determination of production needs in material and } \\
\text { technical resources } \\
\text { 2.Collect information about suppliers } \\
\text { 3.Choice of suppliers }\end{array}$ \\
\hline Production & $\begin{array}{l}\text { 1. Minimization of the parties size and unconditional } \\
\text { execution } \\
\text { 2. Equalizing the loading of production } \\
\text { 3. Rational placement of production equipment } \\
\text { 4. Statistical quality control of the technological process }\end{array}$ \\
\hline 1. Planning the order \\
2. Transfer of the order \\
3. Choice of goods and ordering \\
4. Deliverv of the order
\end{tabular}

\subsection{Organization of logistic flows}

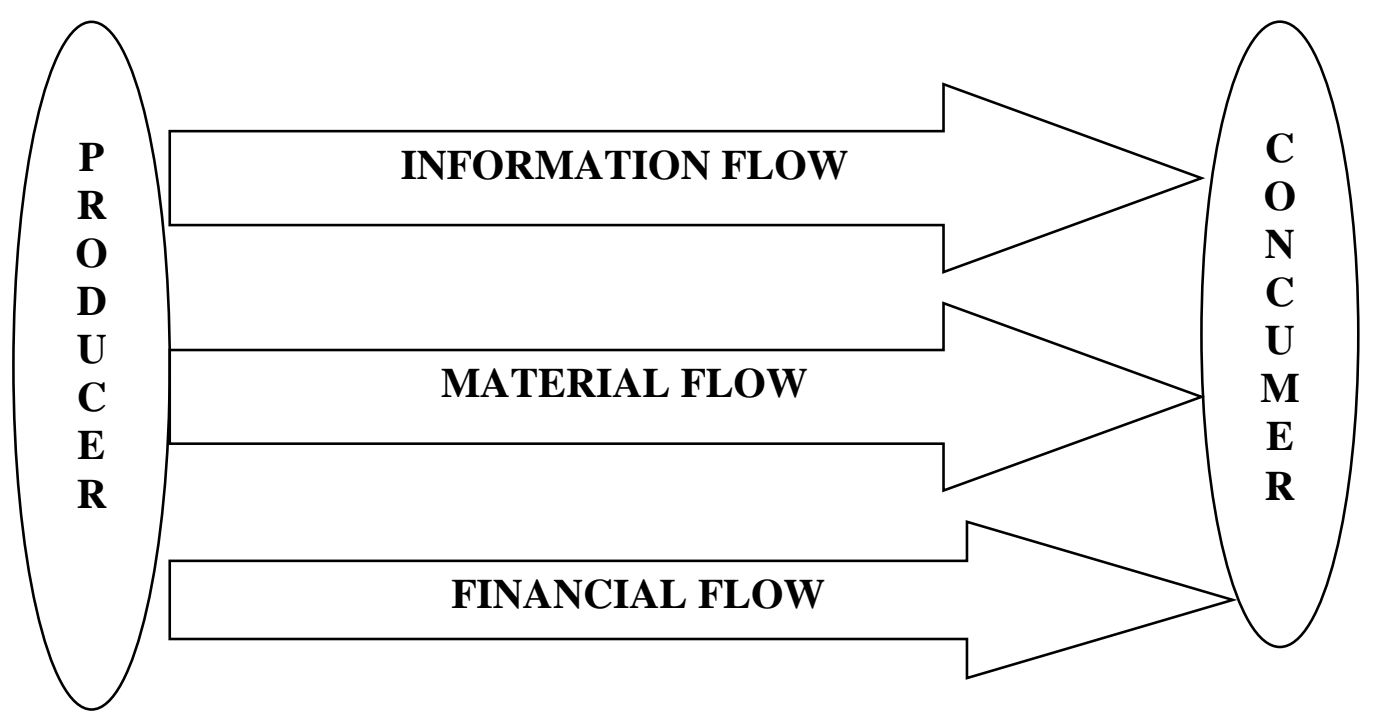

\section{Fig.2.4. Logistic flows [25, 26]}

Material flows are material resources (MR), incomplete production (IP) and finished products (FP), to which the logistic activities related to their physical movement in space are 
applied: loading, unloading, docking, crossdocking, transportation, sorting, consolidation, divestment, etc.

The material flow is characterized by a certain set of parameters and can be classified according to different criteria (nomenclature, assortment and quantity of goods items; weight properties (total weight, gross weight, net weight); physical and chemical characteristics of the cargo; characteristics of the container (packaging), commodity carrier, vehicle (loading capacity, cargo capacity); terms and conditions of sale and purchase agreements (transfer to ownership, delivery);

conditions of transportation and insurance; financial (cost) characteristics).

Service flows are the flows (intangible, special type of product or activity) generated by the logistics system as a whole or its subsystem (link, element) in order to meet external or internal consumers of business organization.

Financial flows are the directed flows of financial resources associated with material, information and other flows both within and outside the logistics chain. Financial flows arise from the reimbursement of logistic costs and expenses.

Information flows are oral messages, document (paper and electronic) and other forms, the accompany material or service flows [25]. The main features of information flows are the 
nomenclature of transmitted messages, data types, documents, intensity and speed of data transmission, and specific properties.

\section{Conclusions}

1. Supply Chain Management (SCM) is the integration of key business processes that begin with the final end user and cover all suppliers of goods, services and information that add value to consumers and other stakeholders.

2. A logistics system is a relatively stable set of links (structural / functional units of the company, as well as suppliers, consumers and logistic intermediaries) and interconnected and unified logistics processes to implement the corporate strategy of the business.

3. Distribution channels have some properties such as length and width.

4. A logistics cycle essentially defines the structural basis of the logistics system. It is determined by such main functional resources of logistics as supply, production support, and distribution.

5. International logistics flows can be divided into material flows, financial flows, service flows and information flows. 


\section{End-of-chapter Questions:}

1. What is the essence of the concept of Supply Chain Management?

2. What is a logistics system?

3. What is a logistics chain?

4. What is a logistics channel?

5. What is a logistics network?

6 . What is a logistics process?

7. What is a logistics cycle?

8. What is a material flow and what are its main characteristics?

9. How to classify material flows?

10. What are the services flows from the position of logistics, what are their main characteristics?

11. What is financial flow?

12. What are the main characteristics that determine the financial flow?

13. How to classify the financial flows?

14. What are information flows in logistics and their characteristics?

15. What is the role of information flows and what are their main features? 


\section{CHAPTER 3. INTERNATIONAL ASPECTS OF PROCUREMENT LOGISTICS}

3.1. Theoretical Foundations of Procurement Logistics

3.2. Basic Approaches to Choosing a Supplier

3.3. Economic Order Quantity

3.4. The "Just-in-Time" Logistics

Key words: procurement logistics, raw materials, inventory, potential suppliers, Economic Order Quantity, delivery time, delivery terms, lead time, lot size.

\subsection{Theoretical Foundations of Procurement Logistics}

Procurement Logistics is the management of material flows in the process of providing the company with the material resources.

International Procurement Logistics is associated with the processes of purchasing raw materials, components and semifinished products outside the country [27].

The main purpose of Procurement Logistics is to meet the needs of production in raw materials, semi-finished products with the maximum possible efficiency.

The basic tasks of Procurement Logistics are [27, 28]:

- to establish the optimal terms for raw materials and component parts for delivery; 
- to ensure the exact relationships between the number of deliveries of finished products and the needs for them;

- to comply with production requirements for the quality of raw materials and component parts.

The main questions:

- What to buy;

- How much to buy;

- For whom to buy;

- On what conditions to purchase.

List of the key tasks:

- How systematically to associate purchases with production and sales;

- How systematically to link enterprise activities with suppliers.

\subsection{Basic Approaches to Choosing a Supplier}

There are two ways to choose a supplier:

1. Selection of a supplier from among the companies that have been already your suppliers and with which business relationships have already been established.

The main stages of this task:

- to collect information about suppliers;

- to analyze information based on the supplier-selected;

- to make decisions about choosing a supplier. 
2. Selection of a new supplier as a result of search and analysis of the market: a market with which the company has already been working or a completely new market [29, 30].

2.1. Search for potential suppliers.

- announcement of the competition;

- study of promotional materials: corporate catalogs, advertisements in the media, etc.

- visiting exhibitions and fairs;

- correspondence and personal contacts with potential suppliers.

2.2. Analysis of potential suppliers.

Selection criteria

- remoteness of the supplier from the consumer;

- terms of execution of current and extra orders;

- availability of reserve capacities;

- organization of quality management with the supplier;

- psychological climate of the supplier;

- ability to ensure the supply of spare parts throughout the life of the supplied equipment;

- financial position of the supplier.

There are several common methods to choose a supplier: cost-ratio, dominant characteristics; preference categories; rating assessment of factors, etc [29]. 
In most cases, a rating system is used to select how suppliers assess their compliance with the criteria / factors, such as [30]:

1. Reliable delivery.

2. Quality assurance.

3. Production capacity.

4. Price.

5. Location.

6. Technical potential.

7. Financial position.

8. The possibility of compromise.

9. Availability of the information system for communication and order processing.

10. After-sales service.

11. Reputation and role in the industry.

12. Business initiative.

13. Management and organization.

14. Process control.

15. Attitude to the buyer.

16. Image.

17. Registration of goods (packaging).

18. Labor relations.

19. Business experience and relationship history.

20. Supporting documents and instructions. 
As a result of the analysis of potential suppliers, a list of specific suppliers is being formed with which the work on concluding contractual relations is carried out.

In the formulas, the supplier rating $R$ is defined as [31]:

$$
\mathrm{R}=\sum_{\mathrm{i}=1}^{\mathrm{n}} \mathrm{c}_{3} \times \mathrm{k}_{3},
$$

where $\mathrm{n}$ - the number of indicators of the supplier's rating;

$\mathrm{k}_{\mathrm{i}}$ - the indicator value;

$\mathrm{c}_{\mathrm{i}}$ - point assessment of the value provided by the supplier.

\subsection{Economic Order Quantity}

Economic Order Quantity (EOQ) is the quantity of a product that should be ordered so as to minimize the total cost that includes ordering costs and inventory holding costs. The basis for determining a supplier in the procurement logistics is the use of the indicator of the economic (optimal) order quantity [32].

Economic Order Quantity (EOQ) is determined by the formula obtained by F.U. Harris. However, in the theory of inventory management, it is more commonly known as the Wilson's formula:

$$
\mathrm{EOQ}=\sqrt{\frac{2 \times \mathrm{C}_{0} \times \mathrm{S}}{\mathrm{C}_{\mathrm{i}} \times \mathrm{U}}},
$$


where EOQ - economic order quantity, units;

$\mathrm{C}_{0}-$ cost of the order execution, $\mathrm{UAH}$;

$\mathrm{C}_{\mathrm{i}}-$ purchase price per unit of goods, UAH.;

$\mathrm{S}$ - annual sales, units;

$\mathrm{U}-\mathrm{a}$ share of storage costs in a unit price.

This is deduced by differentiating and finding the minima for the equation for the total annual cost, which comprises of the variable purchase cost, the ordering cost and the inventory holding cost. But the EOQ does not depend on the purchase cost since it remains constant for the same annual demand whatever the order quantity [29].

With increasing order quantity, the number of orders to be placed in the year decreases, and, thus the ordering cost decreases but at the same time the inventory holding cost goes on increasing. At the EOQ value, the total cost comprising both these costs is at its minimum value.

\subsection{The "Just-in-Time" (JIT) Logistics}

JIT stands for Just in Time: It is system an operations management system under which the production receives the materials precisely when they are needed. There is no prior production for any anticipated demand. This was pioneered by Toyota at their facilities $[33,34]$. 
The aim of the system is to reduce non profitable activities and make the manufacturing system more flexible, eliminating the associated costs of carrying and maintaining the inventory. There is no scope for Inventory what so ever. The Just-in-Time (JIT) methodology owes its name to the philosophy of doing only what is necessary, when it is necessary, and in required quantity.

The JIT delivery system is a delivery system that is based on synchronizing the delivery of material resources in the required quantity and at a time when the logistics system needs them, in order to minimize the costs associated with inventory creation.

There are various methods in which JIT can be achieved. However, all these methods are important but not exhaustive:

1. Elimination of defects and waste.

2. Balancing the flow and scheduling the output.

3. Multi-skilled labor force to carry out specific operations.

4. Maintenance of equipment and machinery for flawless operations.

5. Cellular manufacturing, i.e., making in small batch sizes.

6. Streamlined design and process flows \& layouts

One of the core ideas of the Just-in-Time management system is the elimination of unnecessary tasks. 
There are several advantages which have been beneficial for organizations who have adopted JIT. Some of the advantages of JIT are listed below:

1.Short setup time and low costs.

2. The flow of goods from warehouse to store shelves.

3. More efficient use of employees with multiple skills.

4. Increased focuse on supplier relationships.

5. Minimizes required storage space, thereby saving storage costs.

6. Smaller chance of inventory breaking/expiring.

\section{Disadvantages of JIT System:}

1. Low stocks cause disruptions in the critical logistics system.

2. The introduction of the system may require major changes, which are difficult to achieve in practice.

3. High transport costs.

4. High dependence on one supplier (failure to comply delivery terms may result in production loss).

5. High dependence on material quality (incoming control costs, claims).

6. A permanent information exchange is required (the obligation to confirm the financial status of the supplier and the producer). 
7. The need for suppliers to move production and warehouses closer to the consumer.

8. Large losses due to suppliers from specialization in crisis situations.

\section{Table 3.3 - Comparative peculiarities of traditional delivery and $« \mathrm{JIT} »$ delivery $[15,30]$.}

\begin{tabular}{|c|c|c|}
\hline Factors & JIT Concept & $\begin{array}{c}\text { Traditional delivery } \\
\text { approach }\end{array}$ \\
\hline Stocks & $\begin{array}{l}\text { 1. All efforts should be } \\
\text { directed to eliminate stocks } \\
\text { 2. There are no insurance } \\
\text { reserves }\end{array}$ & $\begin{array}{l}\text { Majority of } \\
\text { stocks - obsolete stocks }\end{array}$ \\
\hline $\begin{array}{l}\text { Procurement of material } \\
\text { resources }\end{array}$ & $\begin{array}{l}\text { 1. The lot (order) size } \\
\text { covers only the current } \\
\text { need } \\
\text { 2. The purchase is carried } \\
\text { out in small lots with the } \\
\text { parts of the supplier }\end{array}$ & $\begin{array}{l}\text { Procurement is carried out } \\
\text { in large batches with } \\
\text { frequent suppliers }\end{array}$ \\
\hline Suppliers & $\begin{array}{l}\text { 1. Considered as partners } \\
\text { 2. Relations with only } \\
\text { suppliers } \\
\text { 3. The cooperation is a } \\
\text { character of a long-term } \\
\text { national communications } \\
\text { based on long-term } \\
\text { contracts } \\
\text { 4. A small number of } \\
\text { suppliers }\end{array}$ & $\begin{array}{l}\text { A large number of } \\
\text { suppliers }\end{array}$ \\
\hline $\begin{array}{l}\text { Choosing a shipping } \\
\text { (delivery) method }\end{array}$ & $\begin{array}{l}\text { The main objective is to } \\
\text { ensure the reliability of the } \\
\text { delivery time }\end{array}$ & $\begin{array}{l}\text { 1. The main objective is } \\
\text { ensuring the low transport } \\
\text { costs. } \\
\text { 2. The delivery schedule is } \\
\text { assumed by the supplier }\end{array}$ \\
\hline Production quality & $\begin{array}{l}\text { 1. The main purpose is the } \\
\text { absence of defects in } \\
\text { products } \\
\text { 2. The controlling quality } \\
\text { process is made and } \\
\text { assumed by the supplier. }\end{array}$ & $\begin{array}{l}\text { 1. A small number of } \\
\text { defects (up to 2\%) is } \\
\text { allowed } \\
\text { 2. Quality control is carried } \\
\text { out by the seller, who bears } \\
\text { responsibility for it }\end{array}$ \\
\hline
\end{tabular}




\section{Conclusions}

1. Procurement logistics consists of activities such as market research, requirements planning, make-or-buy decisions, supplier management, ordering, and order controlling. Procurement logistics goals can be conflicting: maximizing efficiency by focusing on core competences, outsourcing while maintaining the company's autonomy, or minimizing procurement costs while maximizing security within the supply process.

2. The main purpose of procurement logistics is to meet the production needs for raw materials and semi-finished products with the maximum possible efficiency.

3. The basis for the selection of the supplier in procurement logistics is the use of the indicator of the optimal (economic) number of orders. This indicator is the power of the material flow, directed by the supplier on the ordered by the consumer, and which provides the latter with the minimum value of the sum of two logistics components: transport and procurement costs, as well as the costs of forming and maintaining inventories.

4. The JIT delivery system is a delivery system that is based on synchronizing the delivery of material resources in the required 
quantity and at a time when the logistics system needs them, in order to minimize the costs associated with inventory creation.

\section{End-of-Chapter Questions:}

1. What stands for "procurement" and what terms describe these activities?

2. What are the goals of logistic management in the procurement process?

3. What are the features of procurement process at an industrial enterprise?

4. What are the specific features of procurement process for trading companies?

5. What are typical objectives of procurement at an industrial company?

6. How should an industrial firm establish the relationships between the spheres of management within the procurement?

7. How do the procurement department and other functional divisions of the company interact with each other?

8. What does the process of choosing a supplier in a company during procurement consist of?

9. What factors have to be taken into account when choosing a supplier for an industrial company?

10. What does a general procedure (algorithm) of choosing a supplier consist of? 


\section{CHAPTER 4: LOGISTICS OF INTERNATIONAL STOCKS}

4.1. Theoretical Fundamentals of Inventory Logistics

4.2. Inventory Management

4.3. Analysis of ABC-XYZ in the Inventory Management

4.4. Vendor Managed Inventory (VMI)

Key words: inventories, stocks, active stocks, overstocks, obsolete stocks, inventory management, deficit and surplus, ABC - analysis, vendor, Vendor Managed Inventory.

\subsection{Theoretical Fundamentals of Inventory Logistics}

Several companies have implemented inventory reduction projects and compaigns. But overall, investment in inventories within a supply chain has not gone anywhere. So, inventory management in organisation is a key responsibility of logisticians; in association with other supply chain professionals in planning procurement and operations. Unfortunately, within a business, the accounting system treats inventory as an asset, while logisticians consider inventories as a necessary liability that needs to be minimised. These different views can help to explain why for most enterprises. Inventory Management is not a core consideration within their supply chain structure and strategy [33]. 
Stocks in one form or another are present throughout the length of the logistics chain, both in the sphere of production and in the sphere of product turnover.

Material stocks are products of industrial and technical purpose, which are at different stages of production and circulation, consumer goods and other products that are expected to enter the process of production or personal consumption.

Inventory is the term used for a status variety of materials [4] (Tabl. 4.1).

Table 4.1- The types of inventory [36,4,25]

\begin{tabular}{|c|c|c|}
\hline Inventory function & Inventory form & Driver of demand \\
\hline $\begin{array}{c}\text { Final goods }(F G) \text { for sale } \\
\text { (new and refurbished) }\end{array}$ & $\begin{array}{c}\text { Cycle stock, safety stock, } \\
\text { in-transit inventory, pre- } \\
\text { build inventory to support } \\
\text { market launches }\end{array}$ & $\begin{array}{c}\text { Customer and consumer } \\
\text { demand }\end{array}$ \\
\hline $\begin{array}{c}\text { Service parts (spare } \\
\text { parts) }\end{array}$ & $\begin{array}{c}\text { Service level based on } \\
\text { criticality }\end{array}$ & $\begin{array}{l}\text { Mean time between } \\
\text { failure }\end{array}$ \\
\hline Work in progress (WIP) & $\begin{array}{l}\text { Sub-assemblies awaiting } \\
\text { further production. } \\
\text { Postponement; assemble } \\
\text { to order }\end{array}$ & $\begin{array}{l}\text { FG inventory; production } \\
\text { capacity; customer orders }\end{array}$ \\
\hline Raw materials (RM) & $\begin{array}{l}\text { Dependent demand items. } \\
\text { Component parts; } \\
\text { packing materials }\end{array}$ & $\begin{array}{l}\text { Purchased items required } \\
\text { for production }\end{array}$ \\
\hline $\begin{array}{c}\text { Maintenance, repair and } \\
\text { overhaul (MRO) }\end{array}$ & $\begin{array}{c}\text { Service level based on } \\
\text { criticality }\end{array}$ & $\begin{array}{l}\text { Mean time between } \\
\text { failure }\end{array}$ \\
\hline Consumables & $\begin{array}{l}\text { Support production. Two } \\
\text { bin replacement system }\end{array}$ & Based on production \\
\hline General supplies & $\begin{array}{l}\text { Office and technical } \\
\text { items. Two bin } \\
\text { replacement }\end{array}$ & $\begin{array}{l}\text { As required by the } \\
\text { enterprise }\end{array}$ \\
\hline
\end{tabular}


The role of a logistician is to meet availability objectives by reducing uncertainty and increasing strategic advantage, through understanding the range of external complexity, variability and constraints affecting the organisation and reducing internal uncertainties caused by the conflicting objectives of corporate functions [12].

\section{Inventory management includes:}

1. Inventory policy: measured at the corporate level to determine the amount of money which an enterprise is willing to invest in inventory based on an assessement of the physical options. Development of the Policy is the responsibility of the senior supply chain executive for approval by the Board.

2. Inventory planning: measured at the product or family group level and undertaken by Operations Planning (or similar titled group). The inventory policy is used as the control function in Planning

3. Inventory control: the measurement of actual versus planned inventory, calculated at the stock keeping unit level and undertaken at each location of these, it is Inventory Policy that establishes the rules and limits of managing inventory [36].

The three core sections of analysis are to identify where inventories should be held:

1. The Location: 
- centralised or decentralised locations (the latter is more likely for an enterprise offering on-line ordering and quick home delivery);

- customers and demand channels that could be served from each location;

- company owned and leased premises;

- customer locations;

- supplier distribution centre or warehouse;

- third-party managed location.

2. In what form: raw and packaging materials, part and semifinished goods, finished goods.

3. For what function: cycle stock, safety stock, in-transit inventory, pre-build inventory to support market launches, slow and obsolete (SLOB) inventory required by sales [28].

\section{The main functions of the inventory include:}

1. Process control function. Some stocks are necessary because it takes time to finish one production operation and more or less long time to switch to another operation.

2. Economic function. Some types of stocks at any level provide independence to individual workplaces, polling stations and shops, simplify production and / or distribution processes. But reducing these stocks to a minimum requires some changes in the organization and financing (quality management, 
maintenance, material resources upgrade, personnel training, etc.).

\section{Protection Function against accidents.}

\subsection{Inventory Management}

The main purpose of inventory management is to prevent a production deficit.

There are three types of potential costs for inventory shortages listed below in order of increasing their negative impact [38]:

1. Costs due to the non-fulfillment of the order (delayed sending the ordered product) - additional costs for promotion and dispatch of goods that order, which can not be performed at the expense of available inventory

2. Expenses due to loss of sales - in cases where a regular customer applies for a given purchase to some other organization (such costs are measured in the indicators of revenue lost due to non-implementation of the trade agreement);

3. Costs due to the loss of the customer - in cases where the lack of stocks turns into not only the loss of the trade agreement, but also the fact that the customer begins to constantly searching for other sources of supply (such costs are measured in the indicators of total revenue, which can it would be obtained from 
the implementation of all potential customer contracts with the company).

According to statistics, the shortage of goods is one of the most acute problems for both a seller and a buyer and is often estimated at about $8 \%$ of the total turnover. According to another, equally sad statistics, the surplus of goods in large stores (often called "illiquid") is up to $20 \%$ of the entire range $[39,40]$.

\section{Deficit and Surplus}

A deficit is an excess demand over supply. The deficit indicates a difference in demand and supply and a lack of balancing prices. The deficit may be temporary or permanent. In any case, its consequences are quite obvious - the company loses profits. However, not everything is so simple. If the deficit is a permanent protracted nature, then the consequences may be sadder than it seems at first glance:

- lack of profit due to the too low price;

- direct losses due to a lack of sales;

- the deteriorating of the store image in the eyes of the buyer: "There were never the right products here"; -loss of potential and real customer;

- expenses due to actions aimed at eliminating the deficit moving goods on shelves, urgent search for a substitute product. 
The consequences of the shortage are more related to the environment of the store and are especially dangerous for a company that is at a stage of growth and development, when the conquest of buyers and their loyalty is a strategic goal.

Excess of goods (Surplus of goods) implies: unbalanced price, expiration or sale, mistakes in sales forecasts, excess purchase, commodity cannibalism, changing the consumers' mood or taste, legislative acts, and incompleteness of the goods. To determine the rational amount of stock traditionally used models of optimal order size (Economic Order Quantity models - EOQ) were first proposed back in 1913. The optimization criterion in all these models is the minimum of total costs associated with the size of the order.The most famous and widely used models have a common name - Wilson's formula. All these models are focused on a constant consumption pattern. With an intensive change in consumption Wilson's models do not provide sufficient accuracy for order size estimates. Therefore, in recent years, new methods for calculating the optimal order size, focused on the modern dynamics of consumer markets. Though Wilson models continue to be a necessary tool for obtaining information on the status of inventory management in organizations. 
There are several Wilson's models: the main is to determine the optimal size of the order, with gradual replenishment, taking into account the losses from the deficit and the optimal size of the order in the presence of wholesale discounts.

The moment of placing an order is the to place a restocking order. It depends on the economic size of the order, the time of execution of the order, the consumption of supplies during the period of execution of the order.

The "Minimum-Maximum" system is focused on a situation where inventory and booking costs are so significant that they are comparable to losses from inventory shortages. Therefore, in this system the ordering does not occur specified intervals but only provided that the stocks in the warehouse at that moment were equal or lower than the established minimum level. In the case of issuing an order, its size is calculated so that supplies are replenished stocks to the maximum level. Thus, this system works only with two levels of stocks - the minimum and maximum, which is determined by its name.

\subsection{Analysis of $A B C-X Y Z$ in the Inventory Management}

$A B C$ analysis is a method by which the degree of distribution of a specific characteristic between the individual elements of a plurality is determined. It is based on the assumption that a relatively small number of types of goods, 
which must be repeatedly procured, accounts for a large part of the total cost of goods procured.

The basis of the $A B C$ method lies in the so-called Paretto rule. In accordance with the method of Pareto, the set of controlled objects is divided into two different parts (80/20). Widely used in logistics, the $A B C$ method offers a deeper division - into three parts $[29,30]$.

In terms of inventory management, the $\mathrm{ABC}$ method is a way to standardise and controlling stock, which consists in dividing the nomenclature $\mathrm{N}$, realized inventories into three unequally powerful subsets of $\mathrm{A}, \mathrm{B}$ and $\mathrm{C}$ based on a certain formal algorithm.

In order to conduct $\mathrm{ABC}$ analysis it is necessary:

1) to establish the value of each product (at purchasing prices);

2) to arrange goods at a reduced price;

3 ) to find the amount of data on the amount and cost of the purchase;

4) to break down the goods into groups depending on their share in total acquisition costs.

Depending on the cost commodity stocks are divided into three groups - A, B, C for their share in total acquisition costs. However, the distribution does not necessarily occur in three 
groups, the number of groups and their boundaries are chosen arbitrarily. The most common is the following classification [30]:

Group "A": the most expensive and expensive commodities, which account for about $75-80 \%$ of the total value of stocks, but they account for only $10-20 \%$ of the total amount of goods that are in storage.

Group " $B$ ": the average value of goods. Their share in the total amount of reserves is about $10-15 \%$, but in quantitative terms, these stocks make up $30-40 \%$ of the stored products.

Group " $C$ ": the cheapest. They represent $5-10 \%$ of the total cost of stored products, and $40-50 \%$ of the total storage.

The $A B C$ analysis shows the value of each product group. Usually $20 \%$ of all goods that are in stock accounts for $80 \%$ of all costs. Therefore, for each of the three product groups, a different level of detail is planned for planning and control.

$A B C$ analysis allows classifying the assortment of units by their cost.

This analysis works under the assumption that all inventories are not of equal value for the organization therefore they need to be treated differently. A typical $A B C$ analysis classifies the inventory based on the following table (Tab. 4.2). 
Table 4.2. A typical ABC analysis

\begin{tabular}{|l|l|l|}
\hline \multicolumn{1}{|c|}{ Type of Inventory } & \multicolumn{1}{|c|}{ Type of Importance } & \multicolumn{1}{|c|}{ Type of control } \\
\hline A Items & Very Important & $\begin{array}{l}\text { Accurate records, very } \\
\text { tight control }\end{array}$ \\
\hline B Items & Less important & $\begin{array}{l}\text { Decent records, a little } \\
\text { less tightly control }\end{array}$ \\
\hline C Items & Marginally important & $\begin{array}{l}\text { Only essential records, } \\
\text { light control }\end{array}$ \\
\hline
\end{tabular}

Typically, "A items" consist of minimum number of items but these items account for a major proportion of value for the organization and so on with the other items.

The principle of differentiation of the assortment in the process of $X Y Z$ analysis is different - here the whole range is divided into three groups depending on the uniformity of demand and the accuracy of forecasting.

The group " $X$ " includes goods, the demand for which may slightly fluctuate. The volume of sales for goods included in this group is well anticipated.

The group " $Y$ " includes goods that are consumed in volatile volumes. In particular, products with a seasonal nature of demand may be included in this group. Possibilities to predict demand for goods in this group are average. 
The group " $Z$ " includes goods, the demand for which occurs only occasionally, and any trends are absent. It is difficult to predict sales volumes of this group.

An indication on the basis of which a particular position of the range is assigned to the group $\mathrm{X}, \mathrm{Y}$ or $\mathrm{Z}$ is the demand variation factor $(v)$ for this position.

\subsection{Vendor Managed Inventory (VMI)}

Vendor Managed Inventory (VMI) is a theory based on the integration into supply chain management regarding the system dynamics. In recent years, various partnerships like "Vendor Managed Inventory" (VMI) approach have been used in inventory management. In VMI the vendor (supplier) (someone who is selling something. to retailer network, especially one kind of goods, materials, etc.) manages the stock levels and availability in the customer's warehouse, based on forecast demand [28, 37].

In the traditional inventory management, a retailer makes its own decisions regarding the order size while in $V M I$, the retailer shares his inventory data with the vendor (supplier) so that the vendor is the decision-maker who determines the order size for both. Thus, the vendor is responsible for the retailer's ordering cost, while the retailer has to pay for their own storage cost. This policy can prevent stocking undesired inventories and hence can 
lead to an overall cost reduction. Moreover, the bullwhip effect is also reduced by employing the VMI approach in a buyer supplier cooperation [38].

Thus, VMI is a family of business models in which the buyer of a product provides certain information to a supplier (vendor) of that product and the supplier takes full responsibility for maintaining an agreed inventory of the material, usually at the buyer's consumption location (usually a store). A third-party logistics provider can also be involved to make sure that the buyer has the required level of inventory by adjusting the demand and supply gaps [41].

One of the keys to make VMI work is shared risk. In some cases, if the inventory does not sell, the vendor (supplier) will repurchase the product from the buyer (retailer). In other cases, the product may be in the possession of the retailer but is not owned by the retailer until the sale takes place, meaning that the retailer simply houses (and assists with the sale of) the product in exchange for a predetermined commission or profit (sometimes referred to as consignment stock). A special form of this commission business is scan-based trading, where VMI is usually applied but its use is not mandatory [42]. This is one of the successful business models used by Walmart and many other big box retailers. Oil companies often use technology to manage 
the gasoline inventories at the service stations that they supply. Forexample, Home Depot uses the technique with larger suppliers of manufactured goods. VMI helps foster a closer understanding between the supplier and manufacturer by using electronic data interchange formats, Electronic Data Interchange (EDI) software and statistical methodologies to forecast and maintain correct inventory in the supply chain.

Vendors benefit from more control of displays and more customer contact for their employees; retailers benefit from reduced risk, better store staff knowledge (which builds brand loyalty for both the vendor and the retailer), and reduced display maintenance outlays.

Consumers benefit from knowledgeable store staff who are in frequent and familiar contact with manufacturer (vendor) representatives when parts or service are required. Store staff has good knowledge of most product lines offered by the entire range of vendors. They can help the consumer choose from competing products for items most suited to them and offer service support being offered by the store.

At the goods manufacturing level, VMI helps prevent overflowing warehouses or shortages, as well as costly labor, purchasing and accounting. With VMI, businesses maintain a 
proper inventory, and optimized inventory leads to easy access and fast processing with reduced labor costs [43].

\section{Conclusions}

1. The main purpose of inventory management is to prevent production deficit.

2. Deficit is an excess demand over supply that indicates a difference between demand and supply and the lack of balancing prices.

3. Excess of goods (surplus) implies: unbalanced price, end of expiration or sale, mistakes in sales forecasts, excess purchase, "commodity cannibalism", changing the consumers' mood or taste, legislative acts, and goods incompleteness.

4. ABC - analysis is a method by which the degree of distribution of a specific characteristic between the individual elements of a plurality is determined. It is based on the assumption that a relatively few of types of goods, which must be repeatedly procured, accounts for a major part of the total cost of goods procured.

5. Vendor Managed Inventory (VMI) is a theory based on integration into supply chain management in relation to the system dynamics. In recent years, various partnerships like "Vendor Managed Inventory" (VMI) approach have been used in inventory management. 


\section{End-of-Chapter Questions:}

1. What is the reason for inventory creation?

3. Are there general concepts of inventory management and what are they?

4. What stock is better - maximal, optimal or minimal?

5 . How to classify the stocks?

6. What is the structure of costs related to inventory management?

7. What are the risks of creating and maintaining of inventory?

8. What are deficiency costs and how to calculate them?

9. What is the logistic approach to inventory management?

10. What is the model of inventory management, and what are its parameters?

11. How to determine the Economic Order Quantity (EOQ) necessary for stock formation?

12. What is a "minimum-maximum" inventory management system?

13. What is the ABC method of analysis?

14 . What is a rationing approach to inventory management?

15. What is a XYZ method?

16. What is the essence of Vendor Managed Inventory theory?

17. How to balance a cross inventory management between suppliers / sellers and consumers / vendor managed inventory? 


\section{CHAPTER 5: International Warehouse Logistics}

5.1. Warehouses: Definition, Functions and Classification

5.2. Warehouse Logistics

5.3. Packaging and Barcoding

Key words: warehouse, warehouse area, warehouse map, wholesaler, warehouse management systems, warehouse logistics, packaging, barcode, cross docking.

5.1. Warehouses: Definition, Functions and

\section{Classification}

Warehouse is a place or a building specially designed for receiving, storage, material handling, reconditioning and shipping of products.

Warehouse can be defined as a storage place for products. Warehouse activities include receipt of products, storage, shipment and order picking [37].

Warehouse area consists of storage zones, a mass zone, rack zone, commonzone, bulk zone and distribution zone, receiving and shipping docks, etc [37].

The main function of a warehouse is to store products or goods before moving them to another location.

\section{Warehouses can be considered as follows [37]:}

1. Shipping Hub (when warehouses are placed in a very strategic location, they can become shipping hubs that receive 
shipments until they can be moved to other storage facilities across the country).

2. Assembly Line (where products are delivered by the manufacturer in several pieces, companies can allot areas within their warehouse to assemble products for retailers or customers).

3. Rental Storage Space (whether sales are down or you possess a warehouse that is too big for your stock at the moment, renting space in your warehouse to other businesses is a good option for you if you have space).

\section{Functions of warehouses:}

1.To convert the production assortment to consumer in accordance with demand and in order to fulfill customer orders.

2. To store the products.

3. To consolidate and unload cargoes.

4. To provide services.

The purpose to create warehouses in logistics systems is not the conservation of material resources, but the transformation of material flows for their most effective use.

A warehouse management systems (WMS) is software and processes that allow organizations to effectively manage business processes and warehouse activities, including receiving, putaway, and picking, shipping and inventory cycle counts. It is also includes support of radio-frequency 
communications, allowing realtime data transfer between the system and the warehouse personnel. They also maximize space and minimize material handling by automating putaway process.

A warehouse map can be printed from WMS system or it can be displayed on the system screen, namely a diagram of a warehouse zone and the cells of the zone with their indication (where the user can see the type and quantity of goods in this location).

A warehouse management systems (WMS) can differ significantly from warehouse control systems (WCS). The $W M S$ is a weekly activity forecast based on such factors as statistics and trends, whereas the WCS acts like a floor supervisor, working in real time to get the job done by the most effective means.

A stock-keeping unit (SKU) is a unique code assigned by a retail store for inventory management, flow, and sales tracking. For instance, the WMS can tell the system that it needs five of stock-keeping units $(S K U)$ A and five of $S K U$ B hours in advance, but by the time it acts, other considerations may have come into play or there could be a logjam on a conveyor. A warehouse control system can prevent that problem by working in real time and adapting to the situation by making a lastminute decision based on current activity and operational status. 
Working synergistically, WMS and WCS can resolve these issues and maximize efficiency for companies that rely on the effective operation of their warehouse or distribution center. Warehouses are buildings, structures and various devices intended for receiving, placing and storing the goods received on them, preparing them for consumption and release to the consumer $[24,29,30]$.

The main tasks of the warehouse economy:

- to organise the continuous and uninterrupted supply of production appropriate material resources;

- to ensure the quantitative and qualitative stock;

- to reduce the costs associated with the execution of warehouse operations.

\section{Types of warehouses:}

1. Public Warehouses: owned by a government and semistate body. They are available for rent by private firms to store goods.

2. Private Warehouses: owned by private entities to store their own products or equipment.

3. Co-Operative Warehouses: owned by a co-operative where private firms can rent space for storage.

4. Distribution Centers (DC): a short-term storage center located closer to the major market to facilitate the rapid 
processing of oreders and shipment of goods to customers. Unlike a warehouse, the emphasis is on the moving of goods rather than on long-term storage. DC usually proposes a set of different value adding processes (co-manufacturing) such as customization, final assembly, packing, sorting etc. Not all warehouses are distribution centers, but all distribution centers are warehouses. Warehouses act as storage hubs for products, while distribution centers store and fulfill orders in the same space [37].

Warehousing can be much more than the storage of goods. It can be fulfillment center, an assembly line, and so much more. So, the main elements of the warehouses can be as follows:

1.Storage Systems to ensure maximum storage of goods and easy access at all times (climate control for goods that require cooler or warmer environments).

2. Inventory Management Software to keep track of inventory coming in and out of the warehouse. The information system that takes into account the location of all goods received from suppliers, shipments to consumers and other necessary information.

3. Transportation and Moving Equipment to deliver and transport goods to and from the warehouse. 
4. Ample Security to keep the warehouse safe even at downtimes.

\section{The advantages of warehousing:}

1.Improved Inventory Accuracy: Knowing how much inventory you have and how much you have moved means you can plan for the future more precisely.

2. Reduced Stuffing Levels.

3. Protection of Goods: Having a storage facility that fits the needs of your goods it is so important to a business.

4. Central Location: When you source a warehouse close to a customer or manufacturing hub, you can ensure better transit of goods, decreasing the time it takes to move products between places.

5. Superior Flow of Goods: the better flow of goods from manufacturer to end consumer is brought abuot by understanding the best layout of your warehouse and how to store goods optimally to move them fast.

\subsection{Warehouse Logistics}

Warehouse logistics is the management, planning, and organization of operations within a warehouse. This includes managing space, planning shipments, and organizing information so that the warehouse operates to the best of its abilities. It is important tostrive for better warehouse logistics so 
that you can offer customers better delivery times, and drive down costs where possible [24, 29].

Rational implementation of the logistics process in the warehousing is a key to its profitability. Therefore, the organization of the logistics processes is expected to achieve $[24,29,30]$ :

1) rational planning of the warehouse in the determination of working areas, which helps to reduce costs and improve the processing of cargo;

2) efficient use of space when installing equipment, which can increase the capacity of the warehouse;

3) the use of the universal equipment, which performs various warehousing operations, which leads to a significant reduction in the park of lifting vehicles;

4) minimizing the routes of inland freight transportation in order to reduce operating costs and increase the capacity of the warehouse;

5) unification of lots shipment and the centralized delivery, which can significantly reduce transport costs;

6) maximizing the use of information system capabilities, which significantly reduces the time and costs associated with document circulation and information exchange. 
Sometimes the reserves of a rational organization of the logistics process, even not quite significant, derive from simple things: clearing barriers, improvement of the lighting system, and organization of the workplace. Searching the reserves of the efficiency of the warehouse functioning are not trivial things: everything should be analyzed, and the results of analysis should be used to improve the organization of the logistics process [24, $29,30]$.

There are problems of ensuring the warehouse processes:

- the choice between using your own warehouseand a public one;

- the number of warehouses and the location of the warehouse network;

- the size and location of the warehouse;

- the choice of the storage system. 


\section{Table 5.1. Private warehouse vs public warehouse}

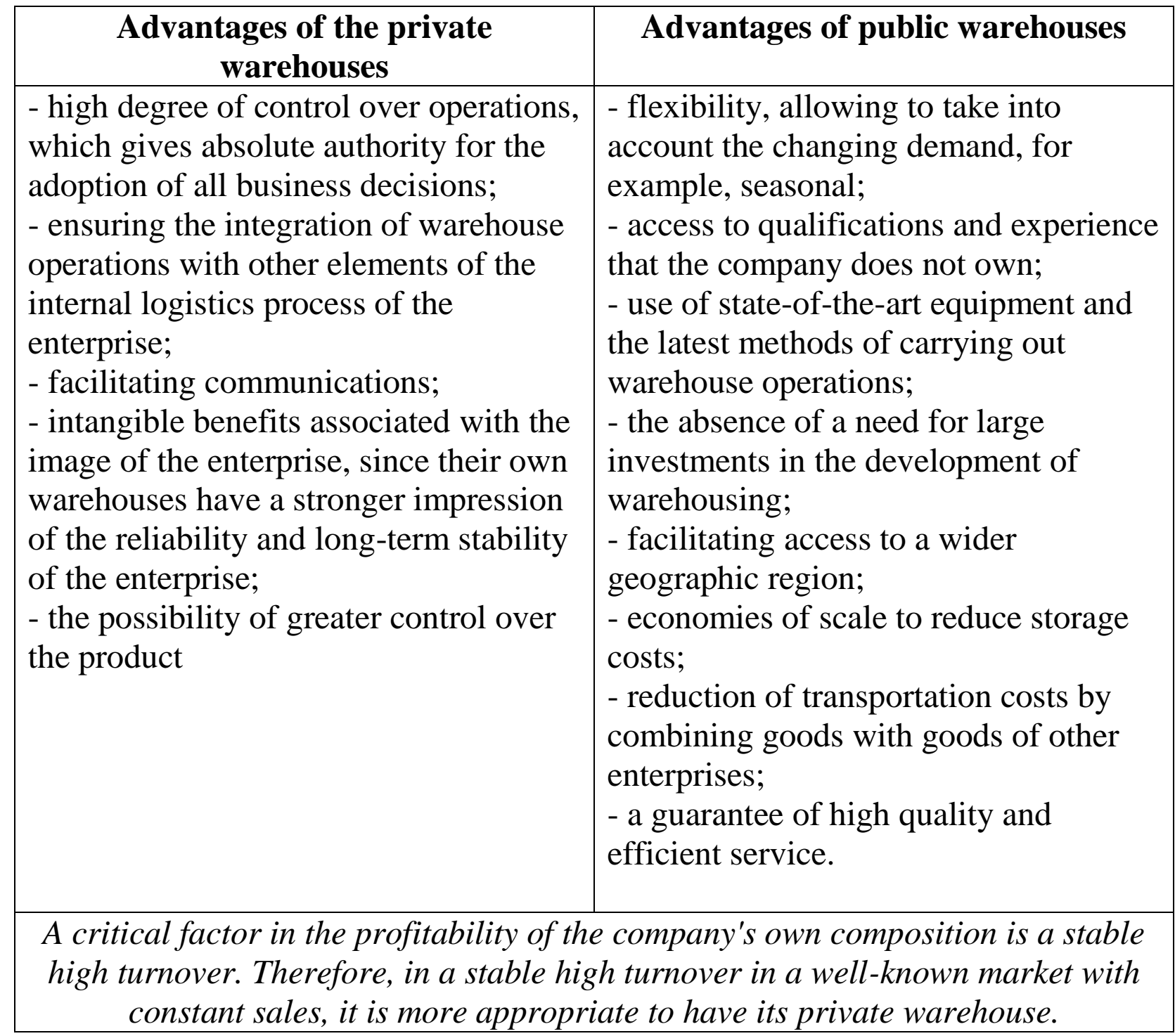

\subsection{Packaging and Barcoding}

Packaging is a process of wrapping goods or putting them in boxes is ready to be sent somewhere and it is one of the means to increase the efficiency of logistic processes in the warehousing.

\section{Types of packaging:}

- internal, or customer, which is addressed to the final consumer of the product and carries out marketing functions; 
- external, or industrial, which provides the convenience of logistics operations.

One of the most important concepts of packaging related to the logistics processes of storage and cargo processing is the concept of a standard consolidated cargo unit. The creation of a consolidated cargo unit is reduced to the physical unification (consolidation) of individual industrial packages into one standardized "package", this is the so-called containerization. Such an aggregate cargo unit can be formed both at production sites and in warehouses.

For containerization, the following can be used:

- rigid containers - devices containing industrial packaging or disassembled ware for storage and transportation;

- non-rigid containers - do not create a closed protective shell for stored and transported products.

The cargoes standardization improves the efficiency of logistic processes - shortens the time of loading and unloading operations, facilitates cargo handling and transport operations, improves the safety of products on the road, simplifies cargo control, increases storage density, speeds up the selection of orders due to a more rational distribution of stocks. All these factors contribute to the reduction of logistics costs [30]. 
For packaging, a barcode printer is used to generate a label to identify batch numbers, serial numbers, and shipping information. This labeling can be used to automatically sort packages for shipment, automate receiving, and greatly enhance package tracking.

Barcode is a series of lines printed on products sold in shops that can be read by a machine connected to a computer to give the price, keep a record of sale, etc. Barcode is a graphical representation of a digital product number in a form suitable for automatic reading with a scanner. It is a visual, machinereadable representation of data; the data usually describes something about the object that carries the barcode. Traditional barcodes systematically represent data by varying the widths and spacings of parallel lines, and may be referred to as linear or one-dimensional (1D). Later, two-dimensional (2D) variants were developed, using rectangles, dots, hexagons and other geometric patterns, called matrix codes or 2D barcodes, although they do not use bars as such. Initially, barcodes were only scanned by special optical scanners called barcode readers. Later application software became available for devices that could read images, such as smartphones with cameras [37]. 


\section{Conclusions}

1. Warehouse can be defined as a storage place for products. Warehouse activities include receipt of products, storage, shipment and order picking.

2. Warehouse logistics is the management, planning, and organization of operations within a warehouse. This includes managing space, planning shipments, and organizing information so that the warehouse operates to the best of its abilities. It is important to strive for better warehouse logistics so that you can offer customers better delivery times, and drive down costs where possible.

3. For packaging, a barcode printer is used to generate a label to identify batch numbers, serial numbers, and shipping information. This labeling can be used to automatically sort packages for shipment, automate receiving, and greatly enhance package tracking.

\section{End-of-Chapter Questions:}

1. What are basic problems of warehouse logistics?

2. What kinds of warehouses does the material flow go through from sources of raw materials to the final consumer?

3. What is a "warehouse network", warehousing of a wholesale trade enterprise and what are the methodological principles of their formation? 
4. What are the basic complex tasks of warehouse network formation of a wholesale trade company?

5. What is the algorithm of warehouse network formation?

6. What kinds of warehouses do exist and how to determine their sizes?

7. What are the methods of analyzing the warehouse system as an element / unit of the logistics system?

8. How to describe a warehouse as an element / unit of the logistics system?

9. What are the advantages of warehousing and principal causes to use warehouses in the logistics system?

10. What are basic functions of the warehouse in a logistics system?

11. What are the major functions of warehousing in the logistics system?

12. How to classify the warehouses in logistics?

13. How do packing and barcoding increase the efficiency of logistics processes in the warehousing? 


\section{CHAPTER 6: Production Logistics}

6.1. Theoretical Fundamentals of Production Logistics

6.2. Logistics Concepts: "MRP" vs "ERP” Systems

6.3. Lean Manufacturing

6.4. Kanban as a Micrologistics System

6.5. Optimized Production Technology

Key words: production logistics, material requirements planning (MRP), enterprise resource planning (ERP), lean manufacturing, Kanban system, optimized production technology (OPT).

\subsection{Theoretical Fundamentals of Production Logistics}

The term production logistics describes logistic processes within a value adding system (factory or a mine). Production logistics aims to ensure that each machine and workstation receives the right product in the right quantity and quality at the right time $[44,45]$.

Production logistics can operate in both existing and new plants: since manufacturing in an existing plant is an ever changing process, machines are replaced and new ones added, making it possible to improve the production logistics system accordingly [45].

Production logistics provides the means to achieve customer response and capital efficiency. Production logistics becomes 
more important with decreasing batch sizes. In many industries (e.g. mobile phones), the short-term goal is a batch size of one that effectively satisfies the need of even one customer. Track and tracing, which is an essential part of production logistics due to product safety and reliability issues, is also gaining importance, especially in the automotive and medical industries.

Production Logistics is one of the functional areas of logistics that explores the processes that take place in the field of material production.

\section{Tasks of production logistics:}

- operational calendar planning with a detailed timetable for the production of finished products;

- general quality control;

- strategic and operational planning of supply of material resources;

- organization of internal production warehousing;

- forecasting, planning and estimating the costs of material resources costs in production;

- control and inventory management;

- physical distribution of material resources and finished products;

- information and technical support of processes of management of internal productive material flows, etc. 
Table 6.1. Concepts of the organization of production at the enterprise [44, 45, 30].

\begin{tabular}{|c|c|}
\hline Traditional concept: & Logistics concept: \\
\hline $\begin{array}{l}\text {-constant and intensive use of } \\
\text { equipment; } \\
\text {-main production in large batches; } \\
\text {-maintenance of the maximum } \\
\text { insurance stocks of material resources. }\end{array}$ & $\begin{array}{l}\text {-refusal from unprofitable stocks; } \\
\text {-refusal of excessive time to perform } \\
\text { basic and transport and warehouse } \\
\text { operations; } \\
\text {-refusal to manufacture those products } \\
\text { for which there is no demand from } \\
\text { customers; } \\
\text {-elimination of irrational internal } \\
\text { productive movements of raw } \\
\text { materials, materials, semi-finished } \\
\text { products; } \\
\text {-transforming suppliers from rivals } \\
\text { into full partners. }\end{array}$ \\
\hline
\end{tabular}

\subsection{Logistics Concepts: "MRP" vs "ERP" Systems}

Manufacturing companies generally require a complex organizational system to keep track of production, inventory, and sales. How manufacturers manage this varies with company size, complexity of production processes, industry vertical, and many other factors.

Most manufacturers use an organizational system called material requirements planning (MRP). The meaning of MRP is exactly what its acronym represents - planning $(\mathrm{P})$ the required (R) materials (M) needed for the manufacturing process.

The MRP software takes additional information - inventory and components from the bill of materials - to determine not 
only the details for the master production schedule but also the net requirements of the manufacturing operations.

Material requirements planning (MRP) is an essential part of any modern manufacturing operation. It makes sense for any manufacturer looking to update their IT portfolio to include the company's MRP requirements in the overall technology requirements planning. But before making any decisions (or even beginning the search for a suitable software system), it is important to be aware of what other technologies are available to the manufacturing enterprise [47].

MRP is software that allows for planning, scheduling, and overall control of materials used in the manufacturing process. The others use an enterprise resource planning (ERP) system instead. In addition to meeting material requirements, ERP systems integrate organizational needs such as accounting, marketing, human resources, and supply chain management [47].

Generally, if manufacturing companies choose a software system other than an MRP to take care of material planning and to help manage the manufacturing process, it will be an ERP system. MRP/ERP systems help to manage inventory, orders, and production scheduling. 


\section{The main objectives of the MRP system:}

- to meet the needs materials for components and products for production planning and delivery to customers;

- to maintain a low level of material resources, unauthorized production and finished products;

- to plan the production operations, delivery schedules, purchasing operations.

\section{Advantages of the MRP system:}

- guarantee of timely receipt of materials and components;

- optimization of warehouse stocks and acceleration of their circulation;

- reduction of the number of cases of non-fulfillment of obligations under contract for the supply of finished products;

- ordering production as a result of controlling the status of each material, from the formation of an order for this material to its implementation in the finished product.

\section{Disadvantages and limitations of the MRP system:}

- a significant amount of computation preparation and preprocessing of a large amounts of source information, which increases the production period and the logistics cycle;

- the growth of logistics costs for orders processing and transportation provided that the company seeks to reduce 
inventory level or switch to the release of finished products in small volumes with high frequency;

- insensitivity to short-term changes in demand, because they are based on inventory control and replenishment at fixed points of the order;

- a large number of failures in the system due to its large dimension and overload.

The MRP I system is an integral part of the MRP II system. In addition to it, the MRP II system includes:

- forecasting and demand management unit;

- calculation of the production schedule (timetable for the output of finished products);

- calculation of the plan for the itilization of production facilities, block placement of orders and control over the procurement of material resources and other units that make up the software package.

MRP II stands for production and resource planning, which evolved from its predecessor, and material replacement planning. MRP II creates detailed production schedules and coordinates component materials with machine and labor availability. MRP II, essentially, addresses the shortcomings of the original MRP and actually expands on what MRP does. It doesn't just manage materials requirements but also addresses 
operational planning, helping with processes such as the following [47]:

1. Shop floor control.

2. Capacity and demand management.

3. Sales and predictions.

4. Item master data.

An important place in the MRP II system take algorithms for forecasting demand, material resource requirements, and inventory levels. In addition, in comparison with the MRP system, a set of tasks for control and regulation of the level of inventories of material resources, the volume of work in progress and finished products on the computer is solved.

The reason ERP systems are so much like MRP systems is that they originated from MRP technology and usage. In the 1960s, when MRPs were first created and used, computers were just becoming widespread in the manufacturing industry. MRPs took advantage of this computing technology to be able to manage cost reporting and materials in the manufacturing process. The technology continued to develop, and in the 1980s, MRP evolved to include master scheduling, rough-cut capacity planning, capacity requirements planning, sales and operations planning (S\&OP), and other concepts. This new generation of manufacturing solution was termed the MRP II [47]. 
In the 1990s, solutions began to be produced that extended the capabilities of material requirements planning and MRP II solutions. While ERP systems didn't replace these solutions, they offered more breadth in functionality and integration. They extended the use of MRP solutions beyond manufacturing to include other types of companies and even government and notfor-profit organizations.

Thus ERPs, like MRPs, are also management software systems, but they offer a much broader coverage of a company's functioning than MRP systems. ERP systems are composed of a collection of integrated modules that cover many disparate departments within a company.

Typical modules in ERP systems include [29, 47]:

- accounting/finance;

- sales and marketing;

- human capital management;

- customer relationship management;

- purchasing management;

- inventory management;

- distribution management;

- quality management.

ERP systems integrate standardized record keeping like their predecessors solutions, but their main function is to allow 
information exchange between many disparate areas of the organization.

An MRP system, on the other hand, is the master production schedule. This master schedule essentially helps with reconciling the final production output and the steps and inputs needed to achieve the production desired. Orders and forecasts are linked to inventory and the time required for each stage of production to ensure the right amount of the right products are finished on schedule.

\section{Enterprise Resource Planning (ERP):}

- supports various types of production and activities of enterprises;

- supports planning of resources in different directions of the enterprise activity;

- ERP-focused virtual enterprise management, reflecting the interaction of production, suppliers, partners and consumers, may consist of autonomous enterprises, corporations or represent a geographically distributed enterprise or a temporary association of enterprises working on individual projects or a state program;

- the advanced tools for system configuration to specific operating conditions (more attention is paid to financial subsystems); 
- has mechanisms to manage transnational corporations, including support for several time zones, languages, currencies, accounting and reporting systems [30].

ERP software incorporates different core processes within a business, such as finance and human resources. Traditionally, these different processes use their own separate software. ERP systems help to integrate management, staff, and equipment into a single system in order to assist with a business's operations. Modern ERP systems also allow for data to be viewed in real time, increasing a company's efficiency, as tasks are completed much faster.

Table 6.7 . "MRP" vs "ERP" [47].

\begin{tabular}{|c|c|c|}
\hline Functionality & MRP II & ERP \\
\hline $\begin{array}{c}\text { Management of material } \\
\text { resources }\end{array}$ & $\begin{array}{c}\text { Formation of orders to } \\
\text { suppliers based on the } \\
\text { production program, } \\
\text { inventory and delivery } \\
\text { terms. Release of materials } \\
\text { into production, receipt of } \\
\text { finished goods }\end{array}$ & $\begin{array}{c}\text { Planning a production } \\
\text { program based on } \\
\text { demand, sales of } \\
\text { finished products, and } \\
\text { payments to suppliers } \\
\text { and buyers }\end{array}$ \\
\hline $\begin{array}{c}\text { Management of productive } \\
\text { resources }\end{array}$ & $\begin{array}{c}\text { Planning the loading of } \\
\text { production equipment to } \\
\text { run the production program }\end{array}$ & $\begin{array}{c}\text { Investment planning for } \\
\text { the production } \\
\text { equipment, accounting } \\
\text { for its use }\end{array}$ \\
\hline $\begin{array}{c}\text { Human resources } \\
\text { management }\end{array}$ & $\begin{array}{c}\text { Planning man-hours in } \\
\text { terms of specialties for the } \\
\text { production support }\end{array}$ & $\begin{array}{c}\text { Ttraffic management } \\
\text { and staff costs }\end{array}$ \\
\hline $\begin{array}{c}\text { Financial resources } \\
\text { management }\end{array}$ & \multicolumn{2}{c|}{$\begin{array}{c}\text { Management of } \\
\text { consolidated budgets for } \\
\text { the financial resources } \\
\text { distribution }\end{array}$} \\
\hline
\end{tabular}




\subsection{Lean Manufacturing}

Lean Manufacturing is a term that has been around now for many years, originally spawned within the study that led to the book "The Machine That Changed the World" by Womack and Jones in 1990. However if you search through the many publications and web sites looking for a lean manufacturing definition you will find a myriad of differing definitions for "Lean", partly because lean is a continuously developing philosophy and because it's application is different for each and every company [48].

The purpose of the Lean Production System is to meet customer needs and do it profitably. Everything within Lean focuses on these two main points, with customer satisfaction first at all times. Everything that you do should provide value to the customer, anything else is waste. If the customer does not explicitly want it, why are you doing it? This is why when you look at any process your first question should always be "WHY?" Too many practitioners of lean jump straight into applying principles to a process without even questioning why the process exists; often they make a wasteful process more efficient and you end up getting better at doing something the customer does not even want. Your customer satisfaction however comes down to just three main areas, usually Quality, 
Cost and Delivery (QCD). Understanding the customers' needs is vital in being able to keep them fully satisfied and everything you do in terms of the provision of services and products should be aimed at meeting those needs. It means giving them the best quality, the right delivery time (which is not always immediate) and the right price.

Lean is also about Delivery; Just - in -Time is about providing a stream using kanban systems to ensure that the customer gets what he wants when he wants. Lean is more than just a cost cutting machine to increase improve profits without any thought about the customer.

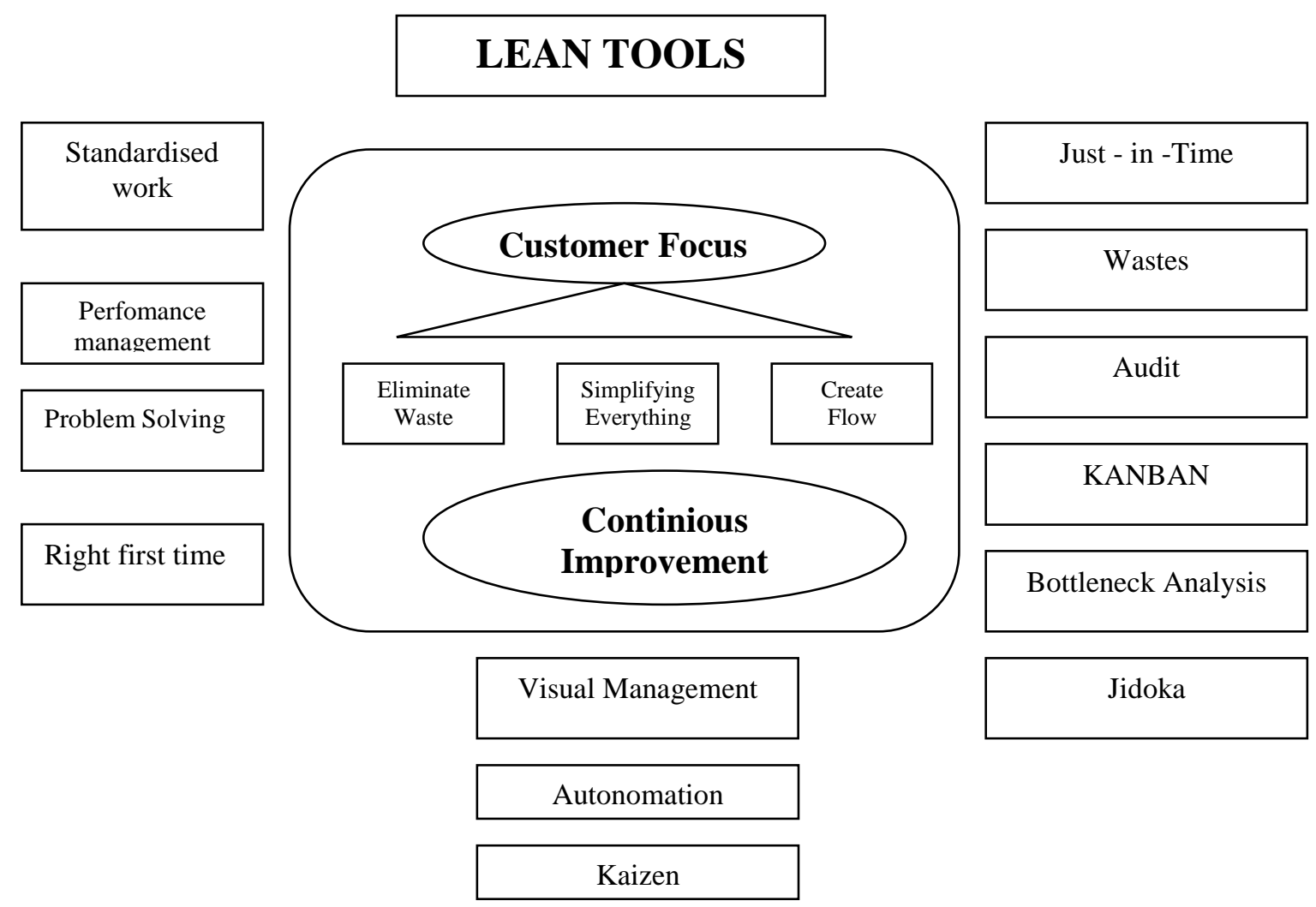

Figure 6.1. Lean Manufacturing Tools [48] 


\subsection{Kanban as a Micrologistics System}

A Kanban is a mechanism to organise a continuous flow of production capable of flexible restructuring, which operates almost in the absence of reserves' insurance.

The essence of the Kanban system is in the fact that all production units of the plant, including the final assembly lines, are provided with material resources only in the amount and in such terms, which are necessary for the fulfillment of the given subsection-consumer order.

A Kanban is a visual method to control production as part of Just in Time (JIT) and Lean Manufacturing. As part of the pull system it controls what is produced, how much, and when. Its purpose is to ensure that you only produce what the customer is asking for and nothing more. It is a system of signals that is used through the value stream to pull product from customer demand back to raw materials. Its literal meaning is that of a flag or sign, when you see that flag, you know that it is time to manufacture the next part. Kanbans can take many forms but in most production facilities they will use Kanban cards or bins to control the process, although there are no limits to how you can control and design kanbans; only your imagination [48]. 
As with Just - in - Time manufacturing the idea behind kanbans comes very much from Toyota and their observation of the Piggly Wiggly supermarket operating in the US. The supermarket would only replenish what customers have taken from the shelves; this would mean that the shelves would never overflow with excessive stock or run empty. This pull was transferred from the customers all the way back to the various suppliers [34].

Just - in - Time was implemented at Toyota company by Taiichi Ohno; it took him over 15 years to perfect the Toyota production. During the 1970s, many western visitors would bring back Kanban cards and want to implement the systems within their own manufacturing facilities; often with little real understanding of how they worked. It was not until the 1980s that Kanban control really started to be understood in the West [35].

\section{Push Production vs Pull Production}

Traditionally production processes are scheduled, raw materials are ordered, and then manufactured to create stock based on a forecast of what the customer is expected to order. This is push production and is driven very much by the materials being fed into the start of the process and all processes being controlled through a schedule or MRP. This typically 
manufactures products in large quantities or batches and ties up a huge amount of your capital in stock and Work in Progress (WIP).

Just-in-time production is accomplished by a "pulling" system instead of a "pushing" system which is traditional for most production. In the traditional production system, including the previously cited MRP system, the production schedule of the final product is "exploded", to determine the requirements of all subassemblies and component parts that make up the final product.

Allowing for adequate production time, the production schedules for all subassemblies and component parts are developed. As the component parts are produced they "push" on or up to the next production stage and eventually are "pushed" to the final product assembly stage. If everything goes well, all component parts and subassemblies will be completed or delivered on time and final assembly can take place as scheduled. Since delays can occur at any of the numerous production stages, the production schedules are usually provided with buffer times or buffer inventories to ensure that delays of a limited number of parts out of thousands of parts and subassemblies do not delay the final product assembly. 
The "push" system (Fig. 6.2) is not only the traditional way of producing products; it is also the current method of production in all American manufacturing plants. The method is, however, traditional for most Japanese firms which have adopted the just-in-time production process that is a "pull" process of production control. In the "push" process, the inventory buildup is considerable and whereas in Japanese firms inventory is measured in days of inventory (three or four days in the automotive firms), in the United States it is measured in weeks of inventory.

In the "pull" system of production contro (Fig.6.3), also called just-in-time production, the more advanced stage of production draws just the right amount of inventory from the preceding process in order to keep going. Each preceding process has, of course, its respective preceding process, and the practice of drawing just the right amount of inventory from each respective preceding process continues right down to the raw material stage, or in the case of purchased parts or subassemblies, down to the parts or subassembly delivery stage. 


\section{PUSH}

PRODUCTION

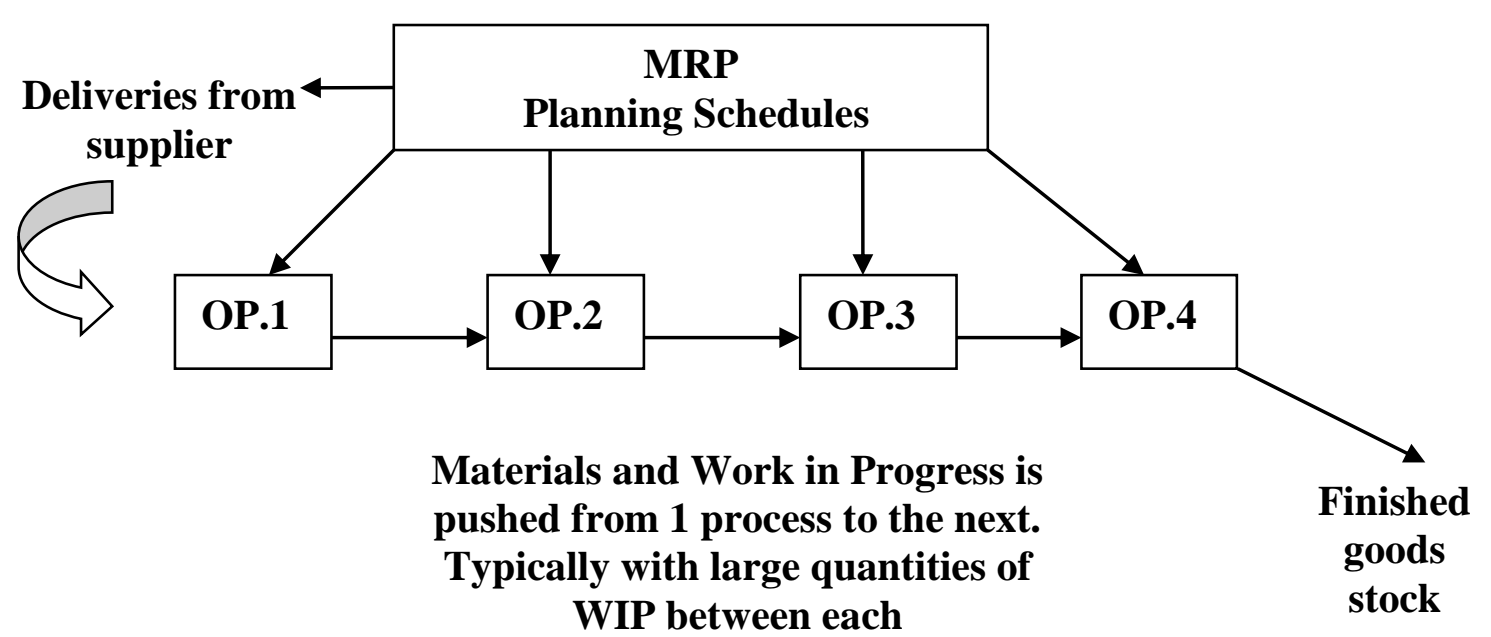

\section{Fig. 6.2. Push production $[44,48]$}

Pull production however works in reverse, when a customer takes a product from the end of your production process a signal is then sent back down the line to trigger the production of the next part. Just as a supermarket will fill the empty shelf each preceding process in the flow will request the parts that it needs from its preceding process [44]. This process is controlled through the use of a Kanban. 
PUII

PRODUCTION

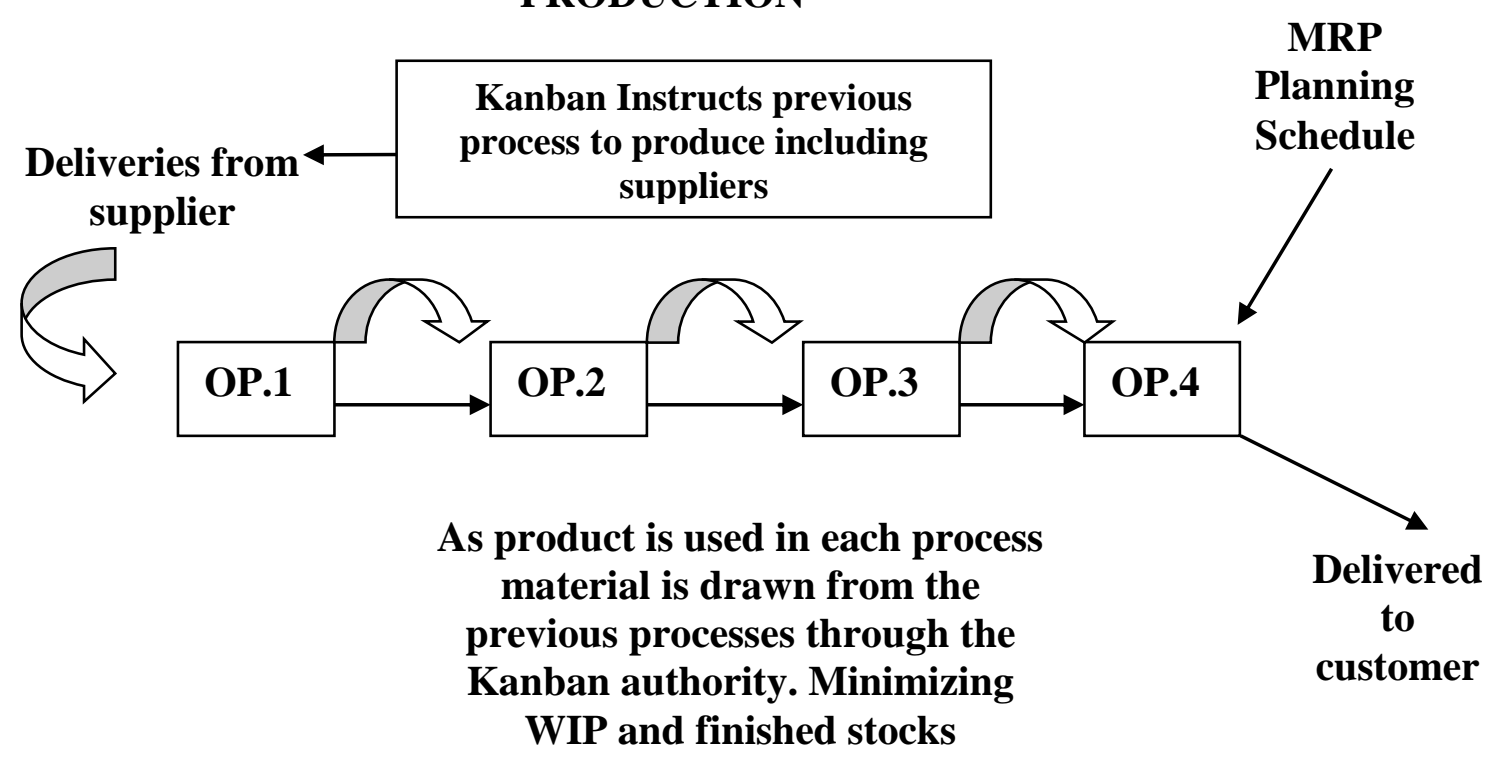

\section{Fig. 6.3. Pull production $[44,48]$}

\section{Implementing a Kanban System means [44, 48]:}

1. Earlier processes never push production onto later processes

2. Nothing is ever made without Kanban authority

3. Nothing is made if there are no Kanbans

4. You have to be able to identify defects as close to the source as possible

5. You cannot operate with large batches or lots of plan changes 6. Where possible, demand should be smoothed. 


\section{Basic Kanban System}

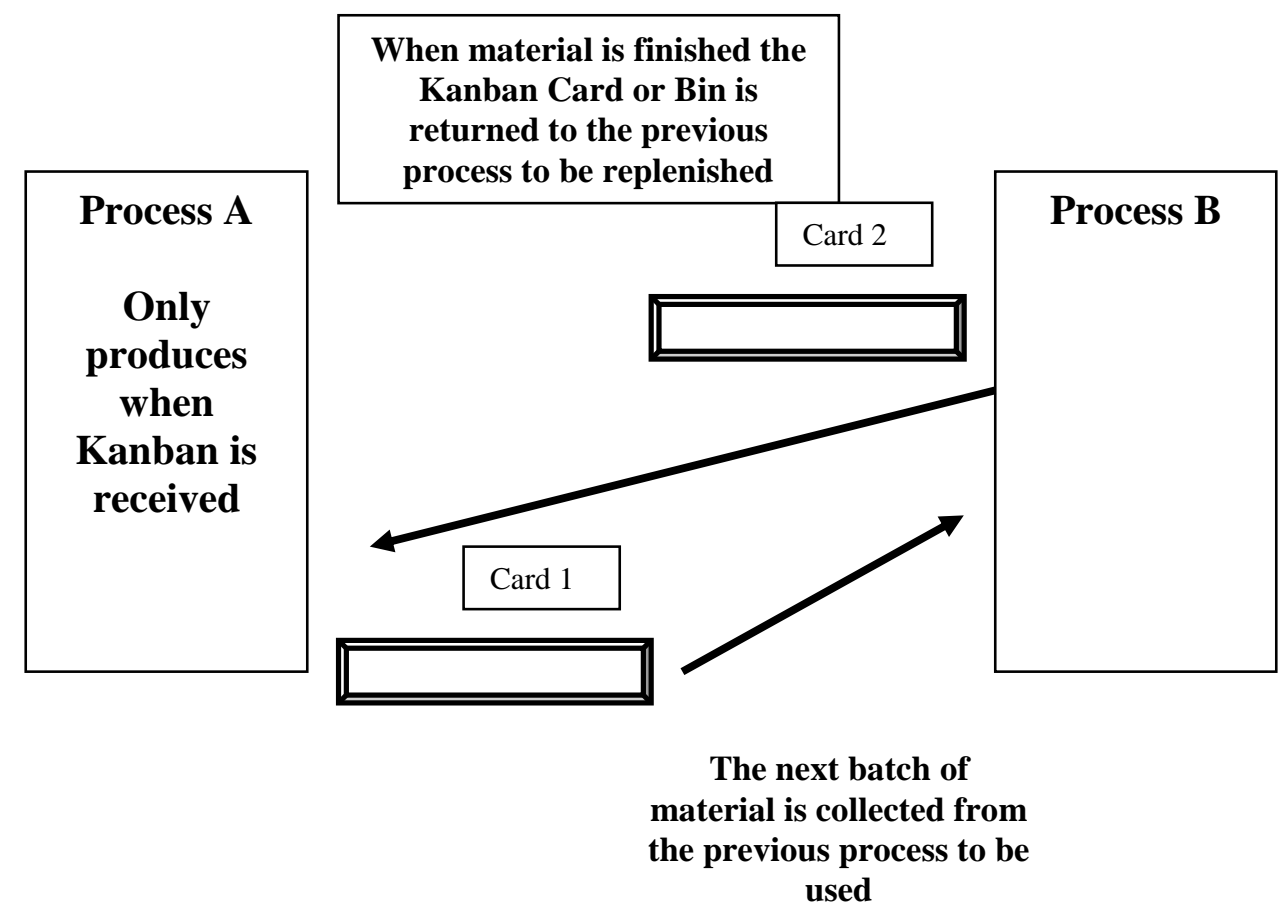

Fig.6.4. Basic Kanban System [44, 48]

Of course, production is rarely as simple as this. Many processes just could not manufacture one product at a time economically and quickly enough even with rapid change overs. We also have many production lines making multiple products for the customer. All of these things complicate things and require a little more thought to be put into designing the system.

Kanban Rules:

1. The later process collects product from the earlier process

2. The later process informs the earlier process what to produce

3 . The earlier process only produces what the later process needs

4. No products are moved or produced without Kanban authority

5. No defects are passed to the later process 
Decreasing the size or number of kanbans within the system will increase the systems sensitivity to changes or problems. This is often the best way to highlight issues within the process and to drive improvements

\section{Ideal Environment for Kanban Implementation}

The main conditions for Kanban Implementation:

1. Regular demand from the customer: If your customer demand is highly irregular and difficult to predict it can be hard to hold Kanban stocks in the traditional supermarket style. You may end up holding larger than necessary stock and work in progress levels without some careful thought about organizing your system.

2. Low product variation: If you make many hundreds or even thousands of different products then you will not want to hold stocks of them all as this could easily increase the amount that you hold. You will want to reduce this burden by ensuring that there are many commonly used parts between products and that you make the product unique as late in the process as possible.

3.Clear flow: Facilities that are organized in a silo style with all similar processing being done in one location are hard to control with a kanban system; although not impossible by any 
means. A better arrangement is one in which all processes are organized together to provide a flow line or cell.

4. Small dedicated machines: Many companies will invest in large all singing all dancing machines that will service all products that they make. Often these machines will drive the use of large batches and will be a bottleneck for the facility. Far better if smaller dedicated machines are used within product flow lines.

5. Quick changeovers: Many machines and processes can take a long time to set up to run a new product or variant. This again drives large batches and can create significant bottlenecks within your production. The use of Single Minute Exchange of Die (SMED) techniques can make a significant impact in this area.

6. Repeatable and reliable processes: If machines are prone to breaking down and processes are not repeatable then it will be hard to control any form of production system let alone Kanban. The use of Total Productive Maintenance (TPM), 5S, operator driven quality improvements, and standardized operations will help you to put in place the foundations that are required.

7. Reliable suppliers: Your suppliers are a vital part of your process and you will need to ensure that they are able to support the kanban processes that you wish to implement reliably. 
Not having these conditions does not mean that you cannot implement Kanban and Just in Time. It just means that you will have to put a little more thought into how your systems are designed and how they will work. Often when you are starting out with JIT and Kanban you will start with large Kanban quantities and slowly reduce the amount of stock over time in a planned fashion to highlight and remove problems. Lowering the inventory levels will uncover the many issues that are there.

As with implementing any other lean manufacturing tools you will need to do it as part of an overall philosophy within your business. There is an ideal environment for using Kanban and Just in Time system, and as such you should be always trying to get closer to that ideal. Kanban is not something that is going to work overnight, nor is it something that can be just dropped into place without explanation or training. As with anything - proper preparation and planning will prevent poor performance. So ensure that you have a proper project plan in place to implement Kanban along with the many other important lean manufacturing tools that you need.

\subsection{Optimized Production Technology}

Optimized Production Technology (OPT) - Optimized Production Technology - production system that takes into account capacity constraints in the production process and does 
not attempt to continuously operate at full capacity. The aim is not to produce as many units as possible, but to raise throughput while keeping inventory and production costs low, thereby achieving an efficient, continuous workflow [49].

Optimized Production Technology (OPT) is a production improvement concept used to reduce bottlenecks, increase throughput, reduce inventories and hence reduce overall manufacturing costs. It is mostly used in manufacturing assembly companies and first introduced by Eliyahu M. Goldratt as "Theory of Constraints" (TOC) in his book "The Goal".

The fundamental theory is that the manufacturing assembly line can only produce at the rate of its bottlenecks. The three key performance indicators are used to monitor the results of performance in an assembly line:

1. Throughput.

2. Inventory.

3. Operating Costs.

There are 9 implementation rules in OPT:

1. Balance the production flow to a consistent rate, to a drum beat. The benefit of this is to minimize the work-inprocess inventory. Use "Takt Time" to determine this rate. "Takt Time" is the rate at which a product produced in order to meet with the market demand rate for the product. 
2. Optimal rates that the assembly line produces, the drum beat, should be at the rate the bottleneck rate is at. The nonbottleneck assembly stations should not be running at $100 \%$ their operating rate/speed. These non-bottleneck assembly stations should be rescheduled for less operating hours or their extra capacity redeployed for other uses or shutdown.

3. Effectiveness (activation) and efficiency (utilization) are not the same. "What Should We Do" and "What We Can Do" are not the same. Hence, optimal production scheduling should be done based on the constraints of the total assembly system's bottle-necks. The benefit from this is reduction in work-inprogress inventories and tied up money in non-moving parts.

4. Production downtime at bottlenecks reduces the total production rate of the assembly line. Hence by improving the rate of productivity of bottleneck stations improves the total production rate of the assembly line. And vice versa, downtime at bottlenecks stations reduces total productivity rate of the assembly line.

5. Improving productivity at non-bottleneck stations is useless effort unless, as this does not make the total productivity rate better. Instead it increases the more ideal time and/or in WIP inventory. 
6. WIP inventory should be maintained for the bottleneck workstations to process. This is to ensure bottleneck workstations have enough material to process and prevent it from shutting down due to lack of material to process. Hence, bottlenecks are affected both by its productivity and WIP Inventory.

7. The transfer batch size should be smaller than the process batch size. Reduced in work-in-process inventory and better throughput is obtained when this is practiced.

8. The process batch size should not be fix size. The process batch size at bottleneck workstations should be larger and the process batch size at non-bottleneck workstations should be smaller.

9. Production scheduling should plan both on capacity and priority at the same time $[11,46]$.

It is found that it would be best for small/medium size assembly companies to embark on using $O P T$ to improve their assembly throughput, inventories and operating costs before deciding to implement Lean Manufacturing or Lean Six Sigma. It will also help the company to embark on getting certified to ISO 9001 to put in place a document system and have a reliable quality system in place to ensure the benefits of $O P T$ are properly documented and realized. Implementing $O P T$ without 
proper quality management processes and documentations in place can lead to an implementation failure [50].

\section{Conclusions}

1. Production Logistics is one of the functional areas of logistics that explores the processes that take place in the field of material production.

2. Generally, if manufacturing companies choose a software system other than an MRP to take care of material planning and to help manage the manufacturing process, it will be an ERP system. MRP/ERP systems help to manage inventory, orders, and production scheduling.

3. The essence of the Kanban system consists in the fact that all production units of the plant, including the final assembly lines, are provided with material resources only in the amount and in such terms, which are necessary for the fulfillment of the given subsection-consumer order. Kanban is a visual method to control production as part of Just in Time (JIT) and Lean Manufacturing.

4. Optimized Production Technology is a production system that takes into account capacity constraints in the production process and does not attempt to continuously operate at full capacity. 


\section{End-of-chapter Questions:}

1. What is the essence of production logistics?

2. Define the main tasks of the production logistics.

3. How does the MRP I module operate?

4. What is a MRP II system?

5. What are the ERP class systems?

6. What is a JIT (Just-in-time) logistics technology?

7. What is a Kanban system?

8. What is the essence of Lean production logistic technology?

9. What are the main tools and concepts of the Lean Production?

10. Optimized Production Technology (OPT) as an effective tool of the Lean Production. 


\section{CHAPTER 7: Distribution Logistics}

7.1. Fundamentals of Distribution Logistics

7.2. Distribution Channels

7.3. Logistics Intermediaries in Distribution Channels

7.4. Distribution Centers in Logistics Chains

7.5. Distribution Requirement Planning (DRP)

Key words: distribution logistics, distribution channels, distribution centers, logistics intermediaries, Distribution Requirement Planning.

\subsection{Fundamentals of Distribution Logistics}

Distribution Logistics is a set of interrelated functions implemented in the process of distributing the material flows between different wholesale customers, that is, in the process of goods wholesale $[46,51,5]$.

Distribution Logistics has as the main tasks the delivery of the finished products to the customer. It consists of order processing, warehousing, and transportation. Distribution logistics is necessary because the time, place, and quantity of production differ with the time, place, and quantity of consumption.

Distribution Logistics is the management of transportation, warehousing and other tangible and intangible operations that are carried out in the process of finished 
products' delivery the to the consumer in accordance with the interests and requirements of the latter, as well as the transfer, storage and processing of relevant information. Otherwise, it is also called marketing or marketing logistics. It is advisable, however, to use the term "distribution logistics" as one that most accurately reflects the presence of a controlling influence in the logistics system when final products are delivered to final users $[5,51]$.

The tasks of the distribution logistics at the micro- and macro levels are different. At the enterprise level (micro level)they are as follows:

- optimization of the orders portfolio formation;

- conclusion of contracts with customers for the supply of products;

- ensuring the rhythm and compliance with planned product sales;

- studying and satisfying the needs of the logistics service; -rationalization of parameters, structure and promotion of dynamic material flows;

- optimization of parameters and conditions of commodities storage;

- formation and improvement of the information support system. 
At the macro level, distribution logistics tasks include the following:

- the choice of the scheme of material flow distribution;

- determinating of the optimal number of distribution centers (warehouses) in the territory being served;

- determining the optimal location of the distribution center (warehouse) in the territory served, etc.

Therefore, the main distribution functions include the following:

1. Determination of consumer demand.

2. Accumulation, sorting and placement of finished product stocks.

3. Establishment of economic relations with regard to the supply of goods and the provision of services to consumers.

4. Choice of rational forms of product promotion and organization of trade.

In turn, the planning functions include the following:

1. Development of perspective and operational sales plans.

2. Analysis and evaluation of market conditions.

3.Determination of consumer demand;

4. Formation of an assortment production plan to the order by buyers; 
5. Selection of channels and goods;

6. Planning of advertising campaigns and development of stimulate sales;

7. Setting cost estimates for sales purposes and their constraints. Among the functions of the organization it is necessary to distinguish the following:

1. Organization of warehousing and packaging for the finished products.

2. Organization of sales and delivery of products to consumers.

3. Organization of after-sales service for consumers.

4. Organization of channels of commodity circulation and distribution networks.

5. Organization of training of sales staff and management activity of trade representative offices.

The set of functions concerning control and regulation can be attributed as follows: performance appraisal; control over the implementation of plans; operational regulation of sales activities of the enterprise with taking into account the influence of external and internal factors; statistical, accounting and operational accounting of sales activities (Tab.7.1). 


\section{Table 7.1. Determining the internal and external}

\section{distribution logistics}

\begin{tabular}{|c|c|}
\hline Tasks of internal distribution logistics & $\begin{array}{c}\text { Tasks of external distribution } \\
\text { logistics }\end{array}$ \\
\hline $\begin{array}{l}\text { 1) to organise the receipt and to process } \\
\text { the order; } \\
\text { 2) to plan the implementation process; } \\
\text { 3) to choose the type of packaging, } \\
\text { acceptance } \\
\text { the decision on the complete set, as well a } \\
\text { the organization of the execution of other } \\
\text { operations; } \\
\text { 4) to organise the shipment of products; } \\
\text { 5) to organise the delivery and to control } \\
\text { the transportation; } \\
\text { 6) to organise the after-sales service. }\end{array}$ & $\begin{array}{l}\text { 1) the choice of the architecture of the } \\
\text { commodity channel; } \\
\text { 2) organization of work with channel } \\
\text { participants; } \\
\text { 3) choice of the strategy of distribution } \\
\text { of finished goods; } \\
\text { 4) choice of pricing strategy; } \\
\text { 5) organization of measures for } \\
\text { promotion of products on the market; } \\
\text { 6) control of the state of the enterprise's } \\
\text { product market and analysis of product } \\
\text { positions in the target segments. }\end{array}$ \\
\hline
\end{tabular}

\subsection{Distribution Logistics Channels}

Logistics Channel refers to a network that involves the participants of supply chain engaged in functions like transportation, receiving, handling, warehousing, information sharing, etc. [37]. An efficient logistics channel is pre-requisite for acquisition and retaining of customers as it helps companies to deliver their goods to their customers at the right time in the right condition. An increase in product variety has also led to the need of improved logistics channel.

\section{The various goals of logistics channel are as follows} [52]:

1. Meeting customer service level.

2. Minimized costs. 


\section{Increased sales.}

4. Building relationship for better logistics execution.

Hence, for designing a logistics channel, customer needs are analyzed in order to fix channel objectives. Various types of of restrictions are identified when setting up channels. Then, various alternatives of logistics channel are identified and evaluated. There are many third party logistics companies that provide complete solution related to logistics channel. They partner with the suppliers and help them meeting their objectives at least cost. The suppliers also assess their logistics partners at regular intervals.

A simple logistics channel can be viewed as follows:

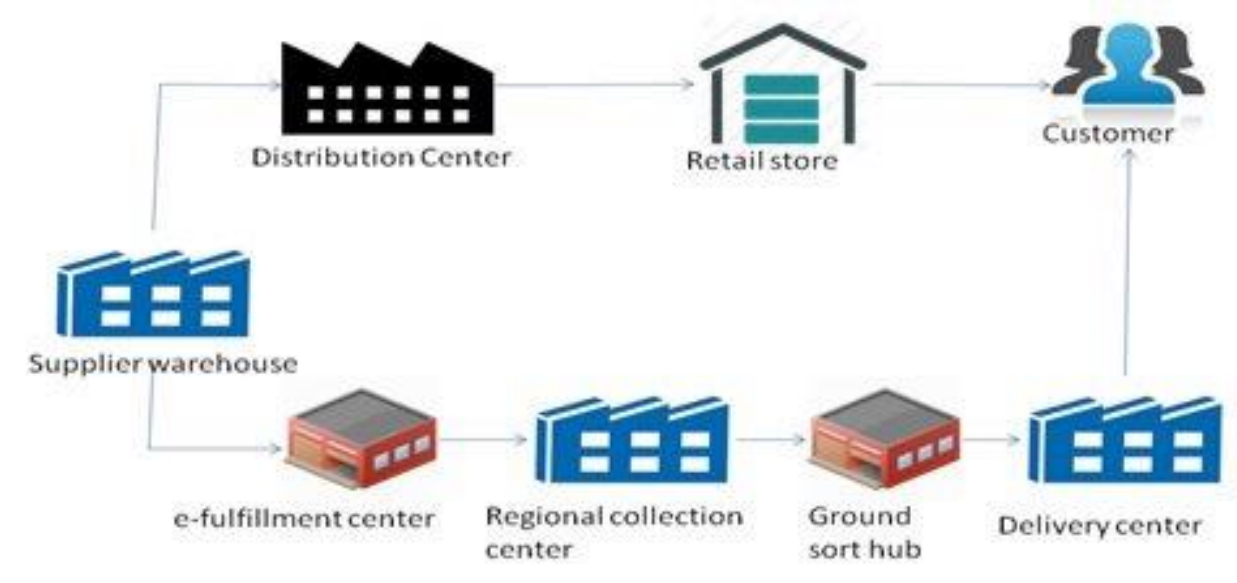

Fig. 7.1. Logistics Channel [52]

The media through which goods or services flows from the producers to the consumers is known as a distribution channel. It involves a series of individuals and organizations who act as 
intermediaries in the system. Distribution channels are also called marketing channels or marketing distribution channels.

Distribution Channels accommodate bidirectional flows such that they allow the flow of goods and services from the vendors to the consumers and at the same time facilitates the flow of payment for the goods/services in the opposite direction from the consumers to the producers. A set of distribution channels is called a distribution network.

A distribution channel can have several stages depending on how many organisations are involved in it [52]:

1. Multistage Channel - a wholesaler buys and stores goods in large quantities and supplies the same to retailers in smaller quantities (for example: apparel is first going from producer to the wholesaler and retailer and then finally to the consumer (Wal-Mart, Big Bazaar, etc.)

2. Single stage Channel - a channel that contains only one intermediary, which is typically the retailer in consumer markets (for example: perishable goods such as foods, etc).

The use of distribution channels gives manufacturers some benefits as follows:

- cost savings for product distribution;

- the possibility to invest savings in the main production;

- the sales in more efficient ways; 
- the high efficiency to ensure wide availability of goods and to bring them to the target markets.

Selected channels directly affect the speed, time, efficiency of movement and preservation of products during its delivery from the producer to the final user.

In this case, enterprises or individuals who form a channel, perform a number of important functions, such as:

1) carry out research work on the collection of information necessary for planning the distribution of products and services; 2) stimulate sales through the creation and dissemination of information about goods;

3) establish contacts with potential buyers;

4) adapt the goods to the requirements of buyers;

5) conduct negotiations with potential consumers of products;

6) organise goods (transportation and warehousing);

7) finance the movement of goods through the distribution channel;

8) assume the risks associated with the operation of the channel.

During the formation of logistics channels, one should be remembered that the involvement of intermediaries, as a rule, extends logistics chains.

Generally, in the distribution logistics channels can be characterized by the number of components of their levels. The 
level of distribution of the logistics flow is any mediator - a logistics system participant that performs distribution functions, transforming material flows in the process of their movement to the final destination. The length of the channel is determined by the number of intermediate levels between the producer and the consumer.

The logistics channel of the zero level includes the producer and the consumer, the distribution of the material flow is carried out directly by the producer. Such channels are often used for supplying products of industrial and technical purpose, especially if large batches, as well as unique products are purchased. They provide for strict regulation of the supply schedule and therefore allow to reduce production cycles and storage space $[25,30]$.

One-, two- or more-level logistics channels include one or more intermediaries. For example, a channel that includes a wholesaler, a wholesaler and a retail intermediary is a threelevel one. In multilevel channels, the distribution of material flows at an initial stage is carried out by the manufacturer, and then by the intermediary structures $[25,30]$.

From the standpoint of producers that generate material flows, the more levels the logistics channel has, the more 
difficult it is to coordinate the functioning of all links to promote material flows to consumers.

\section{Distribution channels may be horizontal and vertical.}

\section{Horizontal distribution channels are traditional channels} and consist of an independent manufacturer and one or more independent intermediaries. Each member of the channel is an individual company that seeks the ways to maximize its profit. The maximum possible profit of a single member of the channel may harm the system as a whole, since none of the channel members has full or sufficient control over the activities of the other members.

Vertical distribution channels are channels that consist of a manufacturer and one or more intermediaries that act as one single system. One channel member, as a rule, either owns the other, or gives them certain privileges. Such a member may be a manufacturer, wholesale or retail intermediary. Vertical channels arose as a means of controlling the behavior of the channel. They are economical and exclude duplication of functions performed by members of the channel. 


\subsection{Logistics Intermediaries in Distribution Channels}

The bodies involved in transacting the product from the producer till the time it gets purchased by the ultimate consumer may be termed as the market intermediaries [37].

Market intermediaries may be represented by individuals or firms. The products keep changing the possession at each level where subsequent transporting and inventory costs get added. Finally the product gets available at the retail outlet at a certain price. Though intermediaries pose a challenge to firms when they compete on the prices yet they are indispensable as a vast distribution network cannot be handled by the company alone $[55,7,53]$.

A marketing intermediary is the link in the supply chain that links the producer or other intermediaries to the end consumer. The intermediary can be an agent, distributor, wholesaler or a retailer. These parties are used in the selling, promotion or the availability of the goods/services through contractual agreements with the manufacturer. They receive the products at a particular price point, add their margins to it and move it to the next link in the supply chain at the higher price point. They are also known as middlemen or distribution intermediaries. 
Logistics intermediaries are a party who arranges shipping, warehousing, distribution and other goods movement on behalf of goods providers and shipping companies [54]. The term third-party logistics, or 3PL, is widely used in logistics circles, also referred as a logistics intermediary. They outsource the firm logistics activities to another firm that then manages the activities, without taking an ownership position in the inventories [54].

The most common intermediaries in International logistics are freight forwarders; after the sale is completed a freight forwarder can handle nearly of all the logistical aspects of the transaction. Indeed, large forwarders may assume responsibility for managing the firm's international distribution and supply channels.

Logistics intermediaries in the distribution channels perform certain functions that can be split up into:

- functions (operations) of physical distribution;

- exchange functions (purchase and sale);

-supporting functions (standardization of distribution quality, financing, information support, risk insurance, etc.)

Export Management Companies (EMCs) are intermediaries that market another firm's products overseas. They have three to five-year exclusive representation contracts, investigate 
potential customers' credit standing, and can handle complementary, non-competitive products. EMCs are professional exporters. An EMC does not manufacture. The business of the EMC is finding and servicing markets overseas on behalf of domestic manufacturers. For example, export packers are a specialized intermediary. They assist the export with special packaging requirments needed to reach some export markets.

\section{The types of logistics intermediaries are as follows [54]:}

1. Wholesalers purchase product in bulk and resell it. They own the products that they sell. They usually sell these products to retailers at a profit. A retailer can be independent, like small kirana stores, or they can be supermarket chains, like Big Bazaar or Reliance Fresh. They own the products that they stock. The retailer is usually the last link of the supply chain, reaching products to the end consumer for a profit.

2. Dealers are the individuals or firms which buy goods from a producer or distributor for wholesale and/or retail reselling. Unlike a distributor, a dealer is a principal and not an agent [53]. Dealers are mostly a wholesale broker that operates on its own behalf and at own expense; he buys the goods under the contract delivery; the relationship between the seller and the dealer are interrupted after execution of all terms of the 
agreement. There are two types of dealers. Exclusive dealers are the only representatives of the producer in the region and have exclusive rights to sell their products. Dealers who cooperate with the franchisee manufacturer are called authorized dealers.

3. Distributors are wholesale and retail intermediaries who carry out operations on behalf of the manufacturer and at their own expense. An entity that buys non-competing products or product lines, warehouses them and resells them to retailers or direct to the end users or customers. Most distributors provide strong manpower and cash support to the supplier or manufacturer's promotional efforts. They usually also provide a range of services (such as product information, estimates, technical support, after-sales services, credit) to their customers [53]. In the logistics chain, distributors usually occupy a position between the manufacturer and dealers. Distributors are different from wholesalers in that the wholesalers carry many product lines, say Tide and Surf Excel, but distributors carry only one of complementary lines, either Tide or Surf Excel products. Distributors will carry these products to points of sale and they maintain very close working relationships with suppliers and buyers. 
4. Commission agents are wholesale and retail intermediaries who carry out transactions on their behalf and at the expense of the manufacturer. The commissioner is not the owner of the product and works on his behalf and at the expense of others.

5. Agents are intermediaries who act as representatives or assistants of another person (principal) who is the principal of him. Typically, agents are legal entities. The agent concludes transactions on behalf and at the expense of the principal. By the scope of authority agents are divided into two categories. Universal agents carry out any legal actions on behalf of the principal. General agents only invest in the contracts specified in the order. The agents receive remuneration for their services both in terms of tariffs and in agreement with the principal. The most widespread form of agency remuneration is the percentage of the amount of the concluded agreements. So, the agent is an independent entity that acts as the manufacturer's representative for the buyer. Agents have possession of the products without actually owning them. They work on acommission basis.

6. A broker is an independent party whose services are used extensively in some industries. A broker's prime responsibility is to bring sellers and buyers together and thus a broker is the third-person facilitator between a buyer and a seller. An 
example would be a real estate broker who facilitates the sale of a property. Brokers are expected to have the tools and resources to reach the largest possible base of buyers and sellers. They then screen these potential buyers or sellers for the perfect match. An individual producer, on the other hand, especially one new in the market, probably will not have the same access to customers as a broker. Another benefit of using a broker is cost they might be cheaper in smaller markets, with smaller accounts, or with a limited line of products [43]. Some types of brokers, such as real estate brokers, often have strict state requirements for using the term, while others, such as aircraft brokers, typically have no formal licensing or training requirements. Some brokers, known as discount brokers, charge smaller commission, sometimes in exchange for offering less advice or services than full service brokerage firms. A broker-dealer is a broker that transacts for its own account, in addition to facilitating transactions for clients [55].

The number and type of intermediaries in the distribution channel is determined by the type of distribution system. Marketing has developed three approaches to solving this problem: intensive distribution, exclusive distribution and selective distribution. 
An intensive distribution involves providing as much inventory as possible to a large number of trading enterprises.

The exclusive distribution involves a deliberately limited number of intermediaries that sell this product within sales territory.

The selective distribution is a bit between methods of intensive and exclusive distribution. The selective distribution allows the manufacturer to reach the required market coverage under more stringent controls and at lower cost than with the organization of intensive distribution.

In order to increase the efficiency of product sales and to save money, organizations often use multi-channel distribution systems.

A significant number of various intermediaries in the distribution channel causes major problems in taking effective decisions. The main problem concerned the coordination of local tasks and objectives of intermediaries with the strategic goals of the manufacturer. In addition, each functional group of mediators also has their complicated relationships. In general, the relationship between the mediators that are formed around this issue can be divided into cooperation, conflict and competition. 
Cooperation is manifested in the fact that intermediary firms performing the same or a different logistic operations in distribution, join forces to achieve a common goal. Conflicts arise when intermediaries have conflicting goals, which concern one and the same area of distribution logistics [2].

\subsection{Distribution Centers in Logistics Chains}

Distribution Center is a warehouse complex, which receives goods from manufacturing companies or from wholesale companies (for example, located in other regions of the country or abroad) and distributes them to smaller parties to customers (small and medium-sized enterprises and retailers) through their own or their commodity network [37].

A distribution center can be understood as a facility that is usually smaller than a firm's main warehouse and is used for receipt, temporary storage, and redistribution of goods according to the customer orders as they are received. They are also called as "branch warehouse" or "distribution warehouse". It should be duly noted that the emphasis here is on processing and moving goods on to wholesalers, retailers, or consumers rather than on storage $[37,55]$.

The key feature of a distribution center is that it is usually "demand-driven". Hence distribution centers are the 
foundation of a supply network, as it is the single location to stock a vast number of products.

In a centralized commodity network, a distribution center dispatches goods produced by a manufacturing to end-users or intermediate consumers in different regions of the country (i.e., wholesalers or wholesale intermediaries, or directly to a retail chain). The advantage of this option is that the manufacturer can redice his stocks of finished products by the manufacturer by sending all the manufactured goods immediately to distribution centers. The disadvantages of this option are high transportation costs for the delivery of goods to numerous buyers and consumers.

With a decentralized distribution system, the total inventory and the cost of several distribution centers will be more expensive than in the previous version. However, the cost of delivering goods to consumers will be lower because distribution centers are in the commodity markets, near consumers. In addition, local distribution centers are easier to explore their regional markets, and they can flexibly respond to the situation in these markets. At the same time, in small regional warehouses it is difficult to achieve the same low cost of processing of goods as in a large automated distribution 
center, which can be observed in a centralized system of organization of the commodity network.

\subsection{Distribution Requirement Planning (DRP)}

DRP (Distribution Requirements Planning) is a system of management and planning that allows not only to take into account market conditions, but also to actively influence it. This system ensures a stable relationship between supply, production and marketing of products using MRP elements [56].

\section{Distribution Requirements Planning (DRP) is the} process in which goods are delivered in a more efficient manner. This includes considering the aspects of product creation, the quantity of theproductand its immediate location where it needs be delivered at a given time. So, DRP is a process that is used to determine which goods or materials will be required at which location and at what time to meet the anticipated demand.

Distribution Requirements Planning will benefit the operation as a whole through the increase in efficiency through the following benefits [56]:

1. Faster decision making.

2. Utilization of demand forecasting.

3. Planning initiation accuracy.

4. Cost awareness. 
5. Customer service enhancement.

6. Push or pull method.

The push method differs from the pull method by doing the opposite of pull - sending the goods downward through the system. This method has advantages of lower cost, but also is at a disadvantage of central planning and demand not necessarily being on the same page at all times. As distribution requirements planning is gradually being implemented into the production facilities and manufacturing operations, there is a drastic increase in production efficiency, accuracy, and order fulfillment.

DRP-II includes maintaining the provision for major noninventory items and resources such as labour, material handling systems, and storage space. It may include other resources such as finances, trucks, freight cars, etc. This information is then entered into an MRP-II (Manufacturing Resource Planning) as gross requirements for estimating and calculating input flows and preparing the schedules of production activities.

The main goal of DRP-II is to eliminate or at least minimize the shortages and at the same time, reduce the costs incurred during ordering, transporting and storing or holding goods. It is also called as Distribution Replenishment Planning. It is a time based approach which estimates when inventory is 
expected to be depleted and accordingly replenishes the same on time [56].

DRP Table forms an important constituent of the DRP-II mechanism. It includes several elements like:

1. Forecast demands

2. Current inventory levels

3. Safety stock

4. Expected replenishment quantities

5. Replenishment lead times

DRP-II works either with the pull or push approach. In the pull method, goods are moved up the network by fulfilling the customer orders. This is a localised approach and as such, customer demands are met in a better way. However, managing the inventory is an issue in this method. In the push method, goods are sent down through the network. It incurs lower costs due to centralised planning and storage of goods. Disadvantage of the push method is that service levels can be affected if central planning is unaware of the actual demand. DRP-II ideally envisages combining the efficiency of push with the service levels of pull.

When managing at the first level, aggregated planning is carried out using forecasts and data on actual orders, the second one - a production schedule is formed, a specific plan with 
specific actions, number of components and finished products is drawn up. And at the third - using the MRP system is used the need and for material resources and production capacities under the production schedule.

The DRP system is the basis for planning logistics and marketing functions, their coordination. It allows to predict market situation with a given degree of probability, to optimize logistics costs by reducing transport costs and expenses on goods, allows to plan supplies and stocks at different levels, the distribution chain, facilitates the implementation of information support at different levels of the distribution chain.

Complex tasks:

1) to plan and to coordinate logistics and marketing;

2) to predict market conditions;

3) to plan a supply;

4) to optimize the logistic costs for conservation;

Micrologistic sales management systems are based on the scheme DRP (Table 7.2). 


\section{Table 7.2. Advantages and disadvantages of the DRP distribution system $[29,30,56]$.}

\begin{tabular}{|c|c|}
\hline & \begin{tabular}{|c|} 
Disadvantages \\
\end{tabular} \\
\hline $\begin{array}{l}\text { 1) improvement of the level of service by } \\
\text { reducing the time of delivery and meeting } \\
\text { the expectations of consumers; } \\
\text { 2) improvement of promotion of the new } \\
\text { products to the market; } \\
\text { 3) the ability to predict and prevent } \\
\text { marketing decisions about the promotion of } \\
\text { finished products with a low stock level; } \\
\text { 4) improved coordination of inventory } \\
\text { control of finished products with other } \\
\text { functions of the firm; } \\
\text { 5) high ability to meet customer } \\
\text { requirements at the expense of the service; } \\
\text { 6) reduction of expenses related to } \\
\text { preservation, transportation, processing of } \\
\text { cargoes; } \\
\text { 7) determining the optimal size of } \\
\text { warehouse space; } \\
\text { 8) the choice of the optimal mode of } \\
\text { transport; } \\
\text { 9) improvement of coordination between } \\
\text { logistics functions in distribution and } \\
\text { production. }\end{array}$ & $\begin{array}{l}\text { 1) the need for a properly } \\
\text { coordinated forecast and } \\
\text { replenishment of funds for each } \\
\text { center and channel in the network of } \\
\text { goods; } \\
\text { 2) the need to determine the } \\
\text { insurance reserves in distribution } \\
\text { centers in order to avoid a possible } \\
\text { mistake in distribution (forecasting } \\
\text { and prediction of time of change in } \\
\text { demand, improper forecasting of } \\
\text { demand affecting warehouse } \\
\text { placement or stock size); } \\
3 \text { ) the need for high reliability of } \\
\text { logistics cycles between distribution } \\
\text { centers and other parts of the } \\
\text { logistics system for inventory } \\
\text { planning; } \\
4 \text { ) an immediate reflection of the } \\
\text { uncertainty of any cycle (order, } \\
\text { transportation, production) on the } \\
\text { efficiency of the solution; } \\
5 \text { ) frequent changes in production } \\
\text { schedules }\end{array}$ \\
\hline
\end{tabular}

\section{Conclusions}

1.Distribution Logistics is the management of transportation, warehousing and other tangible and intangible operations that are carried out in the process of finished products' delivery the to the consumer in accordance with the interests and requirements of the latter, as well as the transfer, storage and processing of relevant information.

2. Distribution Center is a short-term storage center located 
closer to the major market to facilitate the rapid processing of oreders and shipment of goods to customers. Unlike a warehouse, the emphasis is on the moving of goods rather than on long-term storage.

3. DRP (Distribution Requirements Planning) is a system of management and planning is used, which allows not only to take into account market conditions, but also to actively influence it. This system ensures a stable relationship between supply, production and marketing of products using MRP elements.

\section{End-of-chapter Questions:}

1. What is distribution logistics?

2. How do the types and attributes of a product influence the logistic decisions in distribution?

3. What factors do determine the structure of logistics channels in distribution?

4. How to classify distribution systems and structures of logistics channels in distribution?

5. What are the types of intermediaries in distribution and what functions do they perform?

6. What are the functions and what is the classification of trade agents in distribution?

7. What does determine a choice of a number and specialization of intermediaries in distribution and what are the advantages associated with them? 
8. What factors do determine the choice of a distribution channel and the structure of the distribution system?

9. What types of relationships do exist between intermediaries in distribution?

10. Describe the role of distribution centers in logistics chains.

11.What are the advantages and disadvantages of the "DRP" distribution system? 


\title{
CHAPTER 8: Fundamentals of the International \\ Transport Logistics
}

\author{
8.1. Definition and Objectives of Transport Logistics \\ 8.2. Forwarding Service
}

\subsection{Definition and Objectives of Transport Logistics}

Transport is a sphere of material production, which carries out transportation of people and goods. Transportation can be defined as a key complex activity associated with the movement of material resources, work-in-progress or finished products by a particular vehicle in the logistics chain, which in turn consists of complex and elementary activities, including forwarding, cargo handling, packaging, transmission property rights to cargo, insurance, etc [37].

In business, at its most basic level, transportation is simply moving products and materials from one place to another. This includes shipment of raw materials to the manufacturer and movement of finished product to the customer. Transportation also includes the movement of parts to assembly areas as they are assembled $[11,10]$.

Main tasks of Transport Logistics [11]:

- to choose of vehicle type; 
- to optimize the logistics with combined transport organization;

- to define the rational delivery routes;

- to ensure the technological unity of the transport and warehouse process;

- to coordinate the transport and production process.

Transportation is the driver of logistics, but logistics is the race car driver in the seat of transportation. But, in fact, logistics requires planning; transportation is just the mode to execute the planning, when getting freight from point A to point B. Clearly, they are not the same thing, but transportation is just simply a part of logistics [17]

\section{Transportation is needed for [17]:}

1. Movement of raw-materials from suppliers to the manufacturing unit.

2. Movement of work-in-progress within the plant.

3. Movement of finished goods from plant to the final consumers.

When it comes to logistics, logistics executives must make further decisions beyond the mode of transportation to include:

1. Packaging

2. Containerization

3. Documentation 


\section{Insurance}

5. Storage

6. Importing and exporting regulations

7. Freight claims management

8. Choosing the correct LTL freight class for your shipment

9. Working and collaborating with other executives within the supply chain

10. Managing vendors and partners

11. Taling responsibility for mitigating risk and mitigating expenditures

Transportation is that logistical activity which creates place utility.

Major transportation systems include:

1. Railways

2. Roadways

3. Airways

4. Waterways

5. Pipelines.

The choice of a particular mode of transportation depends on the balance of the following considerations:

1. Speed of transportation system

2. Cost involved in transportation

3. Safety in transportation 


\section{Reliability of transportation time schedules}

5. Number of locations served etc.

For most companies, the key to transportation and logistics is finding the right balance between efficiency and cost. Perhaps one of the most successful companies at doing this is Amazon, which has dozens of distribution centers across the United States and spends billions in developing state-of-the-art fulfillment centers to get its products to customers quickly while managing to make a profit.

Transport is essential in ensuring the efficient operation of the logistics system of the enterprise. During the production cycle, all cargoes are moved, which is accompanied by numerous logistics operations. It greatly increases the volume of transport work. For each logistics transaction, there are several transport operations, which leads to significant transport costs (10-30\% of indirect costs in the cost of production).

Based on the goals and objectives of logistics, the company can use automotive, rail, water, air or pipeline transport. The economic feasibility of using one or another type of transit is determined by the following groups of factors [17]:

1.General economic factors: The location and scale of production and consumption of products, which determines the volume and direction of transportation and freight traffic; the 
nomenclature of produced goods, which determines the type of rolling stock and the rhythm of its work; the state of material values, stocks which define the urgency of the delivery of goods, etc.

2.Specific transport factors: placement of the communication network (in-house transport routes); conditions of transport operation, including seasonality and rhythmicity of work; throughput and carrying capacity; technical equipment; system of organization of the transport process.

Logistics costs are directly reduced by just in time, or JIT, manufacturing. Use material resource planning or MRP systems to time orders so that a minimum of stock is on hand. Order parts in packaging that can be directly sent and stocked in the warehouse. This eliminates the wasteful process of receiving, unpacking and then labeling product for the company's own inventory management system. Work with suppliers to have bar code labels or RFID chips that are cross-compatible, allowing the entire supply chain to use the same part numbers and equipment to track and manage inventory.

In the structure of social production transport refers to the sphere of material services production. The cost of transport operations is up to $50 \%$ of the total amount of logistics costs. 
Consolidating shipments increases the risk of a lost shipment bringing a JIT assembly line to a standstill. A surprise shortage will shut down production. This means that JIT requires a secure supply chain. The orders must be able to be delivered quickly and rapidly, with a minimum risk of delays. This is the reason many JIT suppliers build factories or distribution centers close to their major suppliers.

If the supplier is close by, a shutdown of air traffic or a massive traffic jam across town will not prevent parts from being walked over. Suppliers that are not located close by must have multiple backup routes for their product. If the overnight delivery truck is unable to depart on time, there needs to be a mitigation plan in place, such as reserve vehicles or shipping companies on retainer that can send out another vehicle and team to unload the vehicle, reload to the new vehicle, and then deliver the parts and material.

\subsection{Forwarding Service}

Enterprises, solving problems regarding transportation of goods under certain conditions, can transfer some of these functions to specialized transport enterprises. Focusing on the main activities, the manufacturer agrees to pay high-quality 
services of independent firms for the implementation of logistics operations, in order to increase its efficiency [12].

Forwarding services - a kind of activity of specialized intermediaries (freight forwarder or forwarding agent) to provide the sender of cargo with additional services related to the preparation of products for movement $[37,20]$.

A freight forwarder or forwarding agent is an individual or a company which organizes shipments for organizations to source goods from the manufacturer to the final point of distribution or consumer $[37,20]$. It may move a wide range of products as cargo, ranging from manufactured goods to raw agricultural products, owing to its expertise in the logistics network. The freight can be taken through a variety of shipping providers, such as ships, trucks, railroads and airplanes. International freights are handled by international freight forwarders, who have expertise in preparing and processing of documentation, customs and shipment.

\section{The main tasks to forward services:}

- registration of necessary transport documents;

- conclusion of a contract of carriage with transport enterprises;

- settlement payments for cargo transportation; 
- organization of loading and unloading works;

- providing information to participants in the transport process;

- insurance of transported goods;

- consolidation of small cargo units;

- simplification of customs formalities, etc.

The freight forwarder does not moves the products itself, rather it acts as an intermediary between shipper and transportation services like cargo shipping, expedited shipping by air and moving goods by truck or rail.

The most economical route is selected out by bids, on the basis of cost, speed and reliability. The freight forwarder establishes relationships with all kinds of carriers, from trucking companies to air freighters, in order to be able to negotiate best possible price for shipment. Freight forwarders have expertise in handling international shipments from one destination to another, which would pose a formidable burden on the client.

The advantages of deploying a freight forwarder are as follows [14]:

1. Reliable transportation of products at competitive rates.

2. Time saving.

3. Relief from burden of international shipping procedures. 
4. Ancillary services like insurance, customs documentation, non-vessel operating common carrier documentation, bills of lading, warehousing, risk assessment and management, methods of international payment.

The attractiveness of forwarding services is defined by the fact that it is inefficient to keep the state of this category of workers and the appropriate fleet of vehicles requiring special premises and repair facilities for each enterprise. Specialized logistics structures perform the necessary work more qualitatively, faster and significantly cheaper, optimizing freight flows and efficiently using existing vehicles.

The main advantages to use the services of freight forwarding companies are as follows $[2,11]$ :

1. Each consignment lot can be transported at the least cost (consolidation of goods).

2. In the forwarding company there is a large range of possible sizes and types of vehicles. It is possible to choose the most suitable aspecific for this load of the vehicle.

3. Customers can prepare the departure without taking into account the presence of the return cargo.

4. The problem of idle, empty rides and incompleteness of vehicles during the period of decline of business activity of the 
enterprise and the shortage of such means during the periods of its increase is excluded.

5. Forwarding services allow customers to reduce the need for vehicles and maintenance staff to a minimum.

6. Cargo flows are streamlined and optimized at all levels.

7. The quantitative parameters are lowered and the structure of scales is improved by increasing the frequency of deliveries $[29,30]$. 
Table 8.1 presents a comparative description of the services provided by various types of forwarding companies. Depending on the nature of the work and the performed operations, transport and forwarding services are divided into three groups [2]:

1. Direct transport services.

2. Loading and unloading work.

3. Forwarding services. There are two types of forwarding services: complex and local. Complex forwarding services cover all types of services from the moment when loads are accepted and until they are unloaded by the customer.They include:

- acceptance of goods for carriage in the consignor's warehouse;

- preparation of cargo for transportation;

- organization of loading on vehicles;

- organization of transportation;

- organization of cargo security;

- organization of unloading of goods and their warehousing on the territory of the client;

- transfer of goods and registration of necessary documentation for this purpose;

- execution of payments for all types of services rendered;

- report to shippers. 


\section{Table 8.1 - Comparative characteristics of logistics services provided by various types of forwarding companies [29, 2].}

\begin{tabular}{|c|c|}
\hline $\begin{array}{c}\text { Type of enterprise, kind of } \\
\text { transport-expeditionary } \\
\text { service }\end{array}$ & The main services \\
\hline $\begin{array}{l}\text { Large enterprises with the } \\
\text { powerful } \\
\text { automobile fleet, an efficient } \\
\text { communication system, an } \\
\text { extensive network of branches } \\
\text { and offices. Providing a wide } \\
\text { range of transportation services } \\
\text { and warehousing. }\end{array}$ & $\begin{array}{l}\text { 1. Organization and carrying out of transportations } \\
\text { at greater distances in interaction with others } \\
\text { forwarder } \\
\text { or other types transport . } \\
\text { 2. Placement of distribution centers in all industrial } \\
\text { areas. } \\
\text { 3. Transportation services with the involvement of } \\
\text { qualitative subcontractors of small transport } \\
\text { firms. } \\
\text { 4. Maintenance of production warehouses in } \\
\text { different industries } \\
\text { 5. Warehousing and transportation of dangerous } \\
\text { goods with the help of special carriage conditions } \\
\text { which are set up on a certain route and depend } \\
\text { ongoods and materials } \\
\text { 5. Transfer can be carried out using specific } \\
\text { transport equipment (trailr, truck, aircraft, etc) } \\
\text { according to safety rules. }\end{array}$ \\
\hline $\begin{array}{l}\text { Small enterprises with a flexible } \\
\text { management system and } \\
\text { organization of technological } \\
\text { process. Specialization in certain } \\
\text { types of services, which, as a } \\
\text { rule, exceed the average level in } \\
\text { the market }\end{array}$ & $\begin{array}{l}\text { 1. Transportation over long distances, or } \\
\text { organization of linear transportations } \\
\text { 2. Placement of distribution centers at the end } \\
\text { lines of transport } \\
\text { 3. Mediation in the organization of transportation } \\
\text { 4. Transportation of liquid cargos }\end{array}$ \\
\hline $\begin{array}{c}\text { A small business or a separate } \\
\text { entrepreneur with limited } \\
\text { resources. Narrow specialization, } \\
\text { providing some low-cost types of } \\
\text { services }\end{array}$ & $\begin{array}{l}\text { 1. Cargo transportation } \\
\text { 2. Shipment for small distances } \\
\text { 3. Transportation at larger distances by one or } \\
\text { several vehicles } \\
\text { 4. Special carriage conditions } \\
\text { 5. Intermediary activities }\end{array}$ \\
\hline
\end{tabular}




\section{Conclusions}

1. Transportation is simply moving products and materials from one place to another. This includes shipment of raw materials to the manufacturer and movement of finished product to the customer. Transportation also includes the movement of parts to assembly areas as they are assembled.

2. A freight forwarder or forwarding agent is an individual or a company which organizes shipments for organizations to source goods from the manufacturer to the final point of distribution or consumer. It may move a wide range of products as cargo, ranging from manufactured goods to raw agricultural products, owing to its expertise in the logistics network.

\section{End-of-chapter Questions:}

1. Give the definition of "transport activity"

2. What are the main tasks of transport activities?

3. What are the technological schemes for the intra-product transportation of goods?

4. What is the content of the operating system of cargo delivery?

5. What is "consolidation of cargo"?

6. What are the main principles of the formation of intraindustry transport activities? 


\section{References}

1. Oxford Dictionary of English (2015). Oxford University Press. [Electronic Resource]. DOI: 10.1093/acref/9780199571123.001.0001.

2. Fundamentals of Logistics. 2019. URL: https://booksforstudy.com/1584072050910/logistika/osn ovi_logistiki.htm

3. Material Handling \& Logistics News: Solutions for Handling Efficiency. $2019 . \quad$ URL: http://www.connectingindustry.com/MaterialsHandlingL ogistics/

4. Корпоративная логистика [Corporation Logistics]. 300 ответов на вопросы профессионалов /Под общ. и научн. редакцией проф. В.И. Сергеева. Москва: ИНФРА-М, 2005. 976 с.

5. McGinnis M. A. (1992) Military Logistics: Insights for Business Logistics, International Journal of Physical Distribution \& Logistics Management Vol 22, 234 p.

6. Ronald H. Ballou, Samir K. Srivastava (2007) Business Logistics: Supply Chain Management, Pearson Education. 345 p.

7. Business Management: Help and Review: Business Cources/ What Is International Logistics? - Definition \& Explanation. Chapter 10. Lesson 8. 2019. URL: https://study.com/academy/lesson/what-is-internationallogistics-definition-lesson-quiz.html

8. Бержанір А. Л., Рибчак В. І., Слободяник Н. П. Логістика [Logistics]: Навчальний посібник. Київ: УВПП, 2009. 257c.

9. Coyle J. J., Bardi E. J., Langley Jr. C. J. (1992) The Management of Business Logistics, $5^{\text {th }}$ ed. St.Paul: West Publishing Co. $254 \mathrm{p}$.

10.Logistics Management: Concept, Significance and Key Activities.2020.URL:http://www.yourarticlelibrary.com/ 
business/logistics-management/logistics-managementconcept-significance-and-key-activities/69534

11.Pierre A. David, Richard D. Stewart (2010) International Logistics: The Management of International Trade Operations. Cengage Learning. 439 p.

12.Stock R. James, Lambert M. Douglas (2001) Strategic Logistics Management. McGraw-Hill - Irwin. 502 p.

13.Martin Christopher (2016) Logistics \& Supply Chain Management. Pearson UK. 328 p.

14.Alan Harrison, Heather Skipworth, Remko Van Hoek, James Aitken. Logistics Management and Strategy. Pearson Education Limited, 496 p.

15.Handfield, R., F. Straube, H. C. Pfohl, A. Wielanod (2013) Trends and Strategies in Logistics and Supply Chain Management. Embracing Global Logistics Complexity to Drive Market Advantage [Text]. Bremen: DVV Media Group GmbH. 84 p.

16.V. Misra, M.I. Kahn, U.K. Singh (2010) Supply Chain Management Systems: Architecture, Design and Vision, North American Business Press. URL: http://www.nabusinesspress.com/jsis/misraweb.pdf

17.Ballou R.H. (1992) Business Logistics Management. Third Edition.Prentice-Hall International, Inc.136 p.

18. Michael H. Hugos (2018) Essentials of Supply Chain Management. 4th Edition. 235 p.

19.Mallik, Susan (2010). "Customer Service in Supply Chain Management". In Hossein Bidgoil (ed.). The Handbook of Technology Management: Supply Chain Management, Marketing and Advertising, and Global Management, vol 2 (1 ed.). Hoboken, New Jersey: John Wiley \& Sons. p. 104 (ISBN 978-0-470-24948-2). 20.Terminology in Logistics. ANNEX Dictionary. European Logistics Association, 1994. 124 p. 
21.Bowersox, D. J., Closs D. J. (1996) Logistical Management: The Integrated Supply Chain Process [Text]. McGraw-Hill Companies.730 p.

22.Christofer Martin (1998) Logistics and Supply Chain Management. L.: Prentice Hall.256 p.

23.Jonson J.C., Wood D.F. (1990) Contemporary Logistics, 4th ed. N.Y.: MacMillan. 345 p.

24.Горбенко О. В. Логістика: навчальний посібник. Київ. Знання, 2014. 315 с.

25.Гаджинский, А. М. Логистика: учебник. 10-е изд., перераб. и доп. Москва: Дашков и К, 2004. 408 с.

26.Балабанова Л.В., Германчук А.М. Логістика (Logistics): підручник. Донецький національний університет економіки і торгівлі імені Михайла Туган-Барановського, Інститут економіки i управління. Львів: Магнолія, 2012. 368 с.

27.Peter Baily, David Farmer, David Jessop (2005) Purchasing Principles and Management. Pearson Education. 427 p.

28.Learn about Logistics. Blog. Inventory management is a core part of your Logistics. 2019. URL: https://www.learnaboutlogistics.com/inventorymanagement-is-a-core-part-of-your-logistics/

29.Кальченко А.Г. Логістика: підручник. КНЕУ ім. Вадима Гетьмана. 2-ге вид. без змін. Київ. КНЕУ, 2006. $284 \mathrm{c}$.

30.Логістика (Logistics): теорія та практика: навчальний посібник/ В. М. Кислий [та ін.]; Мін-во освіти і науки України, Сумський державний ун-т. - К.: ЦУЛ, 2010. $360 \mathrm{c}$.

31.Leenders M. R., Fearon H. E., England W. B. (1989) Purchasing and Materials Management, 9th ed. Homewood: Richard D. Irwin. 267 p.

32. William C.Copacino (1993) Creating the Perfect Order // Traffic Management. P.27. 
33.Just-in-Time (JIT) Logistics. ATOX Technology. 2019. URL: http://www.atoxgrupo.com/website/en/news/justin-time-logistics

34.C. Carl Pegels (1984) "The Toyota Production System Lessons for American Management", International Journal of Operations and Production.URL: https://www.emeraldinsight.com/doi/abs/10.1108/eb054 703 DOI: 10.1108/eb054703.

35.Tersine R.J. (1987) Materials Management and Inventory System. 3rd ed. Elsevior North. Holland Publishing. $232 \mathrm{p}$.

36.APICS Dictionary (1995) 8th Edition. American Production and Inventory Control Society, Inc. 411 p.

37.Англо-русский толковый словарь логистических терминов [Logistics Vocabulary]. Aldata Solution Company, 2008. 45p.

38.Sadeghi, Javad, Mousavi, Seyed Mohsen, Niaki, Seyed Taghi Akhavan (2016). "Optimizing an inventory model with fuzzy demand, backordering, and discount using a hybrid imperialist competitive algorithm". Applied Mathematical Modelling. 40 (15-16): 7318-7335. doi:10.1016/j.apm.2016.03.013. ISSN 0307-904X

39.SAP R/3: Менеджмент / Под ред. М. Ребштока и К. Хильденбранда / Пер. с нем. Минск: ООО «Новое знание», 2001.98 p.

40.Slack Nigel, Chambers Stuart, Harland Christine, Harrison Alan, Jonston Robert (1998) Operations Management. Second Edition. PITMAN Publishing.134p.

41."What Is Vendor Managed Inventory?" Datalliance, 2020. URL: https://www.datalliance.com/what-is-vmi.

42. Vendor Managed Inventory (VMI): Three Steps in Making It Work. 2019. URL: https://scm.ncsu.edu/scmarticles/article/vendor-managed-inventory-vmi-threesteps-in-making-it-work 
43.Spiro, Rosann L., Stanton, William J., Rich, Gregory A. (2003) Management of a Sales Force. 12th ed. MCGRAW HILL/IRWIN SERIES IN MARKETING.

Publisher: McGraw-Hill/Irwin; 11 edition. 592 p.

44.Nyhuis P., Wiendahi Hans-Peter (2009) Fundamentals of

Production Logistics, Springer Berlin Heidelberg. 353 p.

45.Robincon, W. I. (2004) A Theory of Global Capitalism:

Production, Class and State in a Transnational Word [Text]. Baltimore and London: The John Hopkins Uniswersit Press. 15 p.

46.Bin Wu (2000) Manufacturing and Supply Systems Management: A Unified Framework of Systems Design and Operation. Springer London. 540 p.

47.MRP vs. ERP-Top Differences. TEC Blog Post. 2019. URL:https://www3.technologyevaluation.com/research/a rticle/erp-vs-mrp-for-manufacturing-which-softwaresystem-do-you-really-need.html

48.Lean Manufacturing Tools, Techniques and Philosophy / Lean and Related Business Improvement Ideas. 2020

URL: http://leanmanufacturingtools.org/kanban/

49. What is Optimized Production Technology (OPT)? /The Law Dictionary. Featuring Black's Law Dictionary Free Online Legal Dictionary 2nd Ed. URL: https://thelawdictionary.org/optimized-productiontechnology-opt/.

50.OPTi Solutions, 2020 [Electronic Resource].URL: http://www.optimalaysia.com/

51.Alan Rushton, John Oxley, Phil Crouche (2000) The Handbook of Logistics and Distribution Management. Institute of Logistics and Transport. Kogan Page Publishers. 571p.

52.Logistics Channel. 2019. [Electronic Resource].URL: https://www.mbaskool.com/businessconcepts/operations-logistics-supply-chain-terms/12978logistics-channel.html 
53.Business Dictionary. Logistics Intermediary. [Electronic Resource].

http://www.businessdictionary.com/definition/logisticsintermediary.html

54.Logistics Intermediaries [Electronic Resource]. URL: https://www.vskills.in/certification/tutorial/internationallogistics/logistics-intermediaries/

55.Johnston, Kevin B. (2019) "Top 15 Broker-Dealer Firms in 2018". Investopedia. URL: https://www.vskills.in/certification/tutorial/internationallogistics/logistics-intermediaries/

56.Distribution Requirement Planning. URL: https://www.mbaskool.com/businessconcepts/operations-logistics-supply-chain-terms/15020distribution-resource-planning-drp-ii.html 
Навчальне видання

\title{
Ярова Інесса Свгенівна
}

\section{МІЖНАРОДНА ЛОГІСТИКА}

\author{
Конспект лекцій \\ для здобувачів вищої освіти \\ спеціальності 292 «Міжнародні економічні відносини» \\ денної форми навчання \\ (Англійською мовою)
}

Відповідальний за випуск Ю. М. Петрушенко

Редактор С. В. Чечоткіна

Комп’ютерне верстання I. Є. Ярової

Формат 60×84/16. Ум. друк. арк. 8,83. Обл.-вид. арк. 6,84.

Видавець і виготовлювач

Сумський державний університет,

вул. Римського-Корсакова, 2, м. Суми, 40007

Свідоцтво суб'єкта видавничої справи ДК № 3062 від 17.12.2007. 